medRxiv preprint doi: https://doi.org/10.1101/2022.02.16.22270779; this version posted February 17, 2022. The copyright holder for this preprint (which was not certified by peer review) is the author/funder, who has granted medRxiv a license to display the preprint in It is made available under a CC-BY-ND 4.0 International license.

\title{
Systematic analysis and prediction of genes associated with disorders
}

\section{on chromosome $X$}

3 Elsa Leitão, ${ }^{1}$ Christopher Schröder, ${ }^{1}$ Ilaria Parenti, ${ }^{1}$ Carine Dalle, ${ }^{2}$ Agnès Rastetter, ${ }^{2}$ Theresa

4 Kühnel, ${ }^{1}$ Alma Kuechler, ${ }^{1}$ Sabine Kaya, ${ }^{1}$ Bénédicte Gérard, ${ }^{3}$ Elise Schaefer, ${ }^{4}$ Caroline Nava, ${ }^{2}$

5 Nathalie Drouot, ${ }^{5}$ Camille Engel, ${ }^{5}$, Juliette Piard,,${ }^{6,15}$ Bénédicte Duban-Bedu, ${ }^{7}$ Laurent Vil-

$6 \operatorname{lard}^{8,9}$ Alexander P.A. Stegmann, ${ }^{10,11}$ Els K. Vanhoutte, ${ }^{11}$ Job A.J Verdonshot ${ }^{11,12}$, Frank J.

7 Kaiser, ${ }^{1}$ Frédéric Tran Mau-Them, ${ }^{13,14,15}$ Marcello Scala, ${ }^{16,17}$ Pasquale Striano, ${ }^{16,17}$ Suzanna

8 G.M. Frints, ${ }^{11,18}$ Emanuela Argilli, ${ }^{19,20}$ Elliott H. Sherr, ${ }^{19,20}$ Fikret Elder, ${ }^{21}$ Julien Buratti, ${ }^{21}$ Boris

9 Keren, ${ }^{21}$ Cyril Mignot, ${ }^{2,21,22}$ Delphine Héron,, ${ }^{21,22}$ Jean-Louis Mandel, 3,5,23,24,25 Jozef Gecz, ${ }^{26,27}$

10 Vera M. Kalscheuer, ${ }^{28}$ Bernhard Horsthemke, ${ }^{1}$ Amélie Piton, ${ }^{3,5,24,24,25}$ Christel Depienne ${ }^{1 *}$

$11{ }^{1}$ Institute of Human Genetics, University Hospital Essen, University Duisburg-Essen, Essen,

12 Germany

$13{ }^{2}$ Institut du Cerveau et de la Moelle épinière (ICM), Sorbonne Université, UMR S 1127, Inserm U1127, CNRS UMR 7225, F-75013 Paris, France

$15{ }^{3}$ Unité de Génétique Moléculaire, IGMA, Hôpitaux Universitaire de Strasbourg, Strasbourg, 16 France

$17{ }^{4}$ Service de Génétique Médicale, IGMA, Hôpitaux Universitaires de Strasbourg, Strasbourg,

18 France

$19{ }^{5}$ Institut de Génétique et de Biologie Moléculaire et Cellulaire, Illkirch 67400, France

$20{ }^{6}$ Centre de Génétique Humaine, Université de Franche-Comté, Besançon, France.

$21{ }^{7}$ Centre de génétique chromosomique, Hôpital Saint-Vincent de Paul, Lille, France.

$22{ }^{8}$ Aix-Marseille University, INSERM, MMG, UMR-S 1251, Faculté de médecine, Marseille,

23 France

NOTE: This preprint reports new research that has not been certified by peer review and should not be used to guide clinical practice. 
medRxiv preprint doi: https://doi.org/10.1101/2022.02.16.22270779; this version posted February 17, 2022. The copyright holder for this preprint (which was not certified by peer review) is the author/funder, who has granted medRxiv a license to display the preprint in It is made available under a CC-BY-ND 4.0 International license .

${ }^{9}$ Département de Génétique Médicale, APHM, Hôpital d'Enfants de La Timone, Marseille,

France

${ }^{10}$ Department of Human Genetics, Radboud University Medical Center, 6500 HB, Nijmegen,

27 the Netherlands

${ }^{11}$ Department of Clinical Genetics, Maastricht University Medical Center ${ }^{+}$, Maastricht, The

Netherlands

${ }^{12}$ Cardiovascular Research Institute (CARIM), Departments of Cardiology, Maastricht University Medical Center, the Netherlands

13 Unité Fonctionnelle Innovation en Diagnostic génomique des maladies rares, CHU Dijon

${ }^{14}$ Centre de Génétique, Centre de Référence Anomalies du Développement et Syndromes

Malformatifs, et Centre de Compétence Maladies Mitochondriales, FHU TRANSLAD, Hôpital

15 INSERM UMR1231, Equipe Génétique des Anomalies du Développement, Université de

${ }^{16}$ Department of Neurosciences, Rehabilitation, Ophthalmology, Genetics, Maternal and

17 Pediatric Neurology and Muscular Diseases Unit, IRCCS Istituto Giannina Gaslini, 16147

${ }^{18}$ Department of Genetics and Cell Biology, Faculty of Health Medicine Life Sciences, Maastricht University Medical Center+, Maastricht University, Maastricht, The Netherlands 
medRxiv preprint doi: https://doi.org/10.1101/2022.02.16.22270779; this version posted February 17, 2022. The copyright holder for this preprint (which was not certified by peer review) is the author/funder, who has granted medRxiv a license to display the preprint in It is made available under a CC-BY-ND 4.0 International license .

${ }^{21}$ UF de Génomique du Développement, Département de Génétique, Groupe Hospitalier Pi-

49 tié-Salpêtrière, APHP-Sorbonne Université, Paris, France.

$50 \quad{ }^{22}$ APHP, Sorbonne Université, Département de Génétique, Centre de Référence Déficiences

51 Intellectuelles de Causes Rares, Groupe Hospitalier Pitié-Salpêtrière and Hôpital Trousseau,

52 Paris, France

$53{ }^{23}$ Centre National de la Recherche Scientifique, UMR7104, Illkirch 67400, France

$54 \quad{ }^{24}$ Institut National de la Santé et de la Recherche Médicale, U964, Illkirch 67400, France

5525 Université de Strasbourg, Illkirch 67400, France

$56{ }^{26}$ School of Biological Sciences, School of Medicine and Robinson Research Institute, The

57 University of Adelaide, Adelaide, 5005, SA, Australia

$58{ }^{27}$ South Australian Health and Medical Research Institute, The University of Adelaide, Ade-

59 laide, 5005, SA, Australia

$60{ }^{28}$ Research Group Development and Disease, Max Planck Institute for Molecular Genetics,

61 Berlin, Germany.

$62 *$ Correspondence to: Christel Depienne (christel.depienne@uni-due.de) 
medRxiv preprint doi: https://doi.org/10.1101/2022.02.16.22270779; this version posted February 17, 2022. The copyright holder for this preprint (which was not certified by peer review) is the author/funder, who has granted medRxiv a license to display the preprint in It is made available under a CC-BY-ND 4.0 International license .

\section{Abstract}

64 Disease gene discovery on chromosome (chr) $\mathrm{X}$ is challenging owing to its unique modes of

65 inheritance. We undertook a systematic analysis of human chrX genes. We observe a higher

66 proportion of disorder-associated genes and an enrichment of genes involved in cognition,

67 language, and seizures on chrX compared to autosomes. We analyze gene constraints, exon

68 and promoter conservation, expression and paralogues, and report 127 genes sharing one or

69 more attributes with known chrX disorder genes. Using a neural network trained to distin-

70 guish disease-associated from dispensable genes, we classify 235 genes, including 121 of the

71 127, as having high probability of being disease-associated. We provide evidence of an ex-

72 cess of variants in predicted genes in existing databases. Finally, we report damaging variants

73 in CDK16 and TRPC5 in patients with intellectual disability or autism spectrum disorders.

74 This study predicts large-scale gene-disease associations that could be used for prioritization

75 of X-linked pathogenic variants. 
medRxiv preprint doi: https://doi.org/10.1101/2022.02.16.22270779; this version posted February 17, 2022. The copyright holder for this preprint (which was not certified by peer review) is the author/funder, who has granted medRxiv a license to display the preprint in

It is made available under a CC-BY-ND 4.0 International license .

\section{Introduction}

Sex in mammals is determined by a diverging pair of sex chromosomes (chr). Human females have two copies of the $155-\mathrm{Mb}$ chrX while males have a single $\mathrm{X}$ copy and a smaller 30-Mb chrY. Compensation of gene dosage in females is achieved through $\mathrm{X}$ chromosome inactivation (XCI), a process leading to the epigenetic silencing of an entire chrX, apart from two pseudoautosomal regions (PARs). This process happens during early embryonic development, is randomly and independently established in each cell, and stably maintained during further cell divisions. ${ }^{1,2}$ As a consequence, female individuals are cell mosaics, each cell expressing genes from either the maternal or paternal X copy. ${ }^{3}$ A subset of genes, which can be variable between individuals and tissues, escapes $\mathrm{X}$ inactivation and continues to be expressed from both $\mathrm{X}$ chromosomes. ${ }^{4}$

The last two decades have revolutionized concepts of X-linked inheritance, by depicting its unique but multiple forms. ${ }^{1,5}$ The first and most widely described disorders $(>100$ genes) mainly affect hemizygous males and are transmitted through healthy or mildly symptomatic female carriers. Other modes of X-linked inheritance are mainly observed in disorders affecting the central nervous system. Variants in X-linked genes such as $M E C P 2^{6}$, $C D K L 5^{7,8}$ and $D D X 3 X^{9}$ preferentially affect heterozygous females. These variants usually occur de novo, and hemizygous males are either not viable or survive only if variants are hypomorphic or mosaic. Variants in other genes affect hemizygous males and heterozygous females almost equally. The list of X-linked disorders first described as selectively affecting males but turning out to also affect females is continually increasing and include IQSEC $2^{10}$, NEXMIF ${ }^{11} \mathrm{KDM} 5 C,{ }^{12} \mathrm{HUWE} 1,{ }^{13} \mathrm{USP} 9 \mathrm{X}^{14}$ and $C L C N 4 .{ }^{15}$ Lastly, two X-linked disorders, related to $P C D H 19$ and $E F N B 1$, affect heterozygous females and postzygotic somatic mosaic males (due to cellular interference), while hemizygous males are spared. ${ }^{16,17}$ 
medRxiv preprint doi: https://doi.org/10.1101/2022.02.16.22270779; this version posted February 17, 2022. The copyright holder for this preprint (which was not certified by peer review) is the author/funder, who has granted medRxiv a license to display the preprint in

Disease gene discovery on chrX is thus associated with greater challenges, including male-female patient selection and variant interpretation biases, compared to autosomes. ChrX

104 is often omitted from genome-wide analyses in a research context due to the difficulty of

105 dealing with sex dichotomy in bioinformatics pipelines. Identifying novel gene-disease asso-

106 ciations on chromosome $\mathrm{X}$ requires dedicated studies of families with multiple affected

107 males ${ }^{18,19}$ or multiple subjects with matching phenotypes. ${ }^{9}$ The interpretation of X-linked var-

108 iants in sporadic cases and small families remains difficult in absence of extended segrega-

109 tion in the family, which is rarely available. Furthermore, the presence of damaging variants

110 at relatively high frequency in large databases (ExAC, gnomAD) led to question previously

111 established gene-disease associations. ${ }^{20}$ The Deciphering Developmental Disorders (DDD)

112 consortium recently estimated that X-linked disorders overall affect males and females

113 equally and represent $6 \%$ of developmental disorders. ${ }^{21}$ However, despite the remarkable size

114 of the cohort (11,044 affected individuals), this study failed to identify new X-linked disor-

115 der-associated genes.

117 In this study, we first undertook a systematic analysis of all coding genes on human

118 chromosome $\mathrm{X}$ and compared the proportion and characteristics of associated disorders to

119 those on autosomes. In a second step, we investigated the relevance of multiple variables to

120 predict gene-disorder associations. Lastly, we used these predictions to uncover new disease-

121 gene associations supported by the literature as well as by patient data and functional studies. 
medRxiv preprint doi: https://doi.org/10.1101/2022.02.16.22270779; this version posted February 17, 2022. The copyright holder for this preprint (which was not certified by peer review) is the author/funder, who has granted medRxiv a license to display the preprint in

It is made available under a CC-BY-ND 4.0 International license .

\section{Results}

\section{Chromosome $\mathbf{X}$ is enriched in disorder genes and in genes relevant to brain function}

124 Chromosome X comprises 829 protein coding genes annotated in HUGO Gene Nomenclature

125 Committee (HGNC), including 205 associated with at least one monogenic disorder (referred 126 to as 'disorder genes') in OMIM (Fig. 1a). We used the clinical synopsis to compare the pro-

127 portion of disorder genes and their associated clinical features on chrX (available for 202

128 genes) and autosomes (Supplementary Methods, Fig. 1b). We observed a significant and spe-

129 cific enrichment in disorder genes on $\operatorname{chrX}\left(24 \%\right.$ versus $12-22 \%, p=1.87 \times 10^{-3}$; OR=1.5; Fig.

$1301 \mathrm{c}-\mathrm{d}$ and Supplementary Tables 1-4). Furthermore, genes on chrX were significantly more

131 frequently associated with neurological phenotypes than genes on autosomes (77\% versus 55-

$13276 \% ; p=7.01 \times 10^{-3} ; \mathrm{OR}=2.0$; Fig. 1e-f). More specifically, we observed that chrX is enriched

133 in genes associated with intellectual disability (ID; $58 \%$ versus $27-45 \% ; p=5.92 \times 10^{-11}$;

$134 \mathrm{OR}=2.9)$, seizures (46\% versus $\left.23-38 \% ; p=1.12 \times 10^{-4} ; \mathrm{OR}=2.1\right)$ and language impairment

135 (32\% versus $11-24 \% ; p=5.59 \times 10^{-3}$; OR=2.0; Fig. $\left.1 \mathrm{~g}-1\right)$, but not motor development, spastic-

136 ity, or ataxia (Fig. 1m-n; Extended Data Fig. 1a-b; Supplementary Table 5). The difference

137 remained significant when genes associated with provisional gene-phenotype relationships

138 (P), susceptibility to multifactorial disorders (M) or traits (T) (referred to as 'PMT' genes)

139 were included in the comparison (Extended Data Fig. 1c-d; Supplementary Tables 4 and 5).

140 In total, $84 \%$ of known disease genes on chrX are associated with ID, seizures or language

141 impairment and about $30 \%$ are associated with all three clinical outcomes (Fig. 1o).

142

143 Confirmed disorder-associated genes share specific features

144 Despite chrX being enriched in disorder-associated genes, 598 genes (71\%) are not yet re-

145 lated to any clinical phenotype (referred to as 'no-disorder genes'; Fig. 1a). We hypothesized

146 that disorder genes share specific common features that dispensable genes do not exhibit and 
medRxiv preprint doi: https://doi.org/10.1101/2022.02.16.22270779; this version posted February 17, 2022. The copyright holder for this preprint (which was not certified by peer review) is the author/funder, who has granted medRxiv a license to display the preprint in It is made available under a CC-BY-ND 4.0 International license .

147 that could be used to predict genes that remain to be associated with human disorders. To test

148 this hypothesis, we retrieved annotations from different sources and/or calculated additional

149 metrics, including: 1) gnomAD gene constraint metrics: LOEUF (rank of intolerance to loss-

150 of-function (LoF) variants), misZ (intolerance to missense variants score) and synZ (intoler-

151 ance to synonymous variants score); 2) coding-sequence (CDS) length; 3) the degree of ex-

152 ons and promoter conservation across 100 species; 4) the promoter $\mathrm{CpG}$ density; ${ }^{22}$ and 5)

153 gene expression data, conveyed as a tissue specificity measure (tau) and brain-related expres-

154 sion levels from GTEx and BrainSpan resources (Supplementary Table 1).

We investigated whether the distribution of these variables differ between disorder genes and no-disorder genes. As expected, disorder genes had lower LOEUF values and higher misZ scores but similar synZ scores than no-disorder genes. We observed a significant enrichment of disorder genes in the three lowest LOEUF deciles and in the two highest misZ deciles, with the distributions of LOEUF and misZ metrics in the PMT group showing inter-

161 mediate values between disorder and no-disorder genes (Fig. 2a-b). Disorder genes were en-

162 riched in the highest decile of exon conservation, promoter conservation scores and CDS

163 length distribution with an overall distribution that was variable in all groups (Fig. 2c; Ex-

164 tended Data Fig. 2; Supplementary Table 6). Disorder genes tended to present higher pro-

165 moter $\mathrm{CpG}$ density than no-disorder genes, although the difference was not significant. Re-

166 markably, we observed that disorder genes are more broadly expressed (tau<0.6) and show

167 intermediary levels of gene expression in brain-tissues compared to no-disorder genes, for 168 which expression was more often restricted to a few tissues (tau $>0.6)$ and are less expressed in the brain (Extended Data Fig. 2). 
medRxiv preprint doi: https://doi.org/10.1101/2022.02.16.22270779; this version posted February 17, 2022. The copyright holder for this preprint (which was not certified by peer review) is the author/funder, who has granted medRxiv a license to display the preprint in It is made available under a CC-BY-ND 4.0 International license . may influence their relationship to human disease. From the 18 PAR protein-coding genes, only two (SHOX and CSF2RA) have been associated with a medical condition so far. We also observed that disorder genes are significantly depleted in close paralogues compared to PMT/no-disorder genes $\left(p=3.1 \times 10^{-6} ;\right.$ OR $=0.33$; Extended Data Fig. 3a-d). This suggests that highly similar paralogues might compensate pathogenic variants in corresponding X-linked genes.

180 which showed marked differences between the two subgroups, can best differentiate disorder

181 from no-disorder genes. We then focused on the deciles enriched in disorder genes to list the genes in the no-disorder group exhibiting similar characteristics (Fig. 2d). More specifically, we defined thresholds for LOEUF, misZ, and exon conservation scores as follows: LOEUF $\leq$ $0.326(\mathrm{~L}), \mathrm{misZ} \geq 2.16(\mathrm{M})$, and/or exon-score $\geq 0.9491(\mathrm{E}) .149$ of the $205(73 \%)$ disorder genes met one or more L, M or E (LME) criteria (Fig. 2e). Among the 205 disorder genes, 56 genes failing to meet any of the LOEUF/misZ criteria had a smaller CDS length $\left(p=4.20 \times 10^{-}\right.$ ${ }^{9}$ ), indicating that the performance of LOEUF and misZ in differentiating disorder from nodisorder genes depends on CDS length (Extended Data Fig. 3e). Exon conservation alone allowed retrieving eight disorder genes with small CDS for which LOEUF and misZ failed to reach the thresholds (Extended Data Fig. 3e; Supplementary Table 1). When applying the same thresholds to the 598 genes not associated with disease, $127(21 \%)$ genes fulfilled at least one condition and 35 fulfilled at least two criteria (Fig. 2e; Supplementary Table 1). Half $(n=13)$ of the PMT genes also met at least one criterion and seven at least two criteria

194 (Fig. 2e). Altogether, 140 genes shared at least one of the LME criteria with known disorder 195 genes. 
medRxiv preprint doi: https://doi.org/10.1101/2022.02.16.22270779; this version posted February 17, 2022. The copyright holder for this preprint (which was not certified by peer review) is the author/funder, who has granted medRxiv a license to display the preprint in

197 Prediction of novel disorder-associated genes on chrX

198 The threshold approach was limited by the number of variables that could be taken into ac-

199 count to differentiate disorder from no-disorder genes. We then used machine learning to pre-

200 dict remaining disorder genes in a more systematic and unbiased fashion. As most X-linked

201 disorders are associated with neurological features, we trained a neural network (NN) to dis-

202 tinguish two classes of genes: 1) known disorder genes associated with neurological features

203 on all chromosomes and 2) dispensable genes as defined by Karczewski et al. (2020) ${ }^{23}$ (Sup-

204 plementary Methods; Extended Data Fig. 4; Extended Data Fig. 5a-b). We used additional

205 variables including expression data stratified according to sex and data on paralogues (Sup-

206 plementary Tables 7 and 8). Although using data on all chromosomes, the neural network

207 performed remarkably better for genes on chrX, predicting 191 (93\%) of the 205 known dis-

208 order genes on this chromosome using FDR $<0.05$ (Extended Data Fig. 5c-f). 145 of the pre-

209 dicted genes met the LME thresholds (Fig. 2f). The NN confirmed 16 of the 26 PMT genes as

210 disease-associated, 13 of which also met LME criteria (Fig. 2f, Fig. 3a-b). Focusing on the

211598 no-disorder genes on chrX, the NN predicted 235 as disease-associated (FDR < 0.05;

212 Supplementary Table 9; Extended data Fig. 5a). 121 genes (51\%) also met at least one of the

213 LME criteria (Fig. 2f), with four meeting all three, 30 two and 87 genes one criterion (Fig.

$2143 \mathrm{c}$ ). The 114 remaining genes predicted by the NN did not meet any LME criteria (Fig. 3d),

215 whereas only six meeting LME criteria were not predicted by the NN (Fig. 3e). Altogether,

216 these results suggest that the $\mathrm{NN}$ is a valid approach to predict genes remaining to be associ-

217 ated with disease with high accuracy.

218

219 Validation of putative novel disorder genes 
medRxiv preprint doi: https://doi.org/10.1101/2022.02.16.22270779; this version posted February 17, 2022. The copyright holder for this preprint (which was not certified by peer review) is the author/funder, who has granted medRxiv a license to display the preprint in It is made available under a CC-BY-ND 4.0 International license .

220 To provide additional evidence supporting our predictions, we searched for evidence from

221 databases or the literature that variants in the $235 \mathrm{NN}$-predicted genes could indeed result in

222 new X-linked disorders. We first used HGMD and DECIPHER to retrieve the number of sin-

223 gle nucleotide variants and indels of unknown significance reported in each gene and com-

224 pared the number of variants in predicted versus non-predicted gene categories (Supplemen-

225 tary Table 9). This analysis revealed that the $235 \mathrm{NN}$-predicted disorder genes are enriched in

226 point variants compared to non-predicted genes $\left(p=5.3 \times 10^{-6} ; \mathrm{OR}=2.2\right)$, suggesting that this

227 excess is due to pathogenic variants. NN-predicted genes meeting at least one LME criterion

228 had more point variants than predicted genes that do not meet any LME criterion (Fig. 4a-b;

229 Extended Data Fig. 6).

230

231

Second, we used the SysID and Gene2Phenotype (G2P) developmental disorders da-

tabases to compare the overlap of predicted and non-predicted genes (Fig. 4c). Nine of the 16

NN-predicted PMT genes were in SysID (Fig. 3a-b). Three genes (PTCHD1, NLGN3, and

KIF4A), indicated as confirmed SysID genes, were also in G2P. PTCHD1 and NLGN3 are as-

sociated with susceptibility to autism in OMIM, but both were recently confirmed to cause a

monogenic ID disorder frequently associated with autism. ${ }^{24-26}$ A splice site variant in KIF4A

237 was identified in a family with four affected males, ${ }^{27}$ and this finding was recently strength-

ened by the identification of additional de novo or inherited variants causing a range of differ-

239 ent phenotypic manifestations. ${ }^{28,29}$ Focusing on no-disorder genes, $21(9 \%)$ of the NN-pre-

240 dicted genes and 14 (4\%) of the non-predicted genes were in SysID (Fig. 3c-d). Five pre-

241 dicted genes (CSTF2, FGF13, PLXNA3, OTUD5 and STEEP1) were confirmed SysID genes.

242 In addition, six genes (ARHGEF6, CDK16, FGF13, GSPT2, MMGT1 and ZDHHC15) had

243 entries in G2P. Pathogenic variants in OTUD5 and FGF13 respectively cause a severe neuro- 
medRxiv preprint doi: https://doi.org/10.1101/2022.02.16.22270779; this version posted February 17, 2022. The copyright holder for this preprint (which was not certified by peer review) is the author/funder, who has granted medRxiv a license to display the preprint in

244 developmental disorder with multiple congenital anomalies and early lethality, ${ }^{30,31}$ and developmental and epileptic encephalopathy, ${ }^{32}$ both described in 2021. PLXNA3 have been associated with ID and autism spectrum disorders (ASD), ${ }^{33}$ or hypogonadotropic hypogonadism. ${ }^{34}$ Additional evidence from the literature not yet reflected in OMIM or any other database include possibly pathogenic variants described in one or a few families in $Z M Y M 3,{ }^{35} G L R A 2,{ }^{36}$ and GPKOW. ${ }^{37}$ Although some of these genes now have an OMIM disorder entry, their association with a monogenic disorder was not known at the beginning of our study.

Third, we retrieved the number of de novo predicted damaging (truncating or $\mathrm{CADD} \geq 25$ ) variants identified in these genes from the Martin et al. ${ }^{21}$ and Kaplanis et al. ${ }^{38}$ studies. In parallel, we examined exome data from two additional cohorts of patients with developmental disorders, containing mainly patients with intellectual disability (6500 from 2346 families [Paris-APHP cohort] and 1399 individuals from 463 families [UCSF cohort) and extracted predicted damaging variants in NN-predicted genes meeting at least one LME criterion (Supplementary Table 10). This led us to select 13 genes containing de novo damaging variants and additional predicted damaging variants identified in independent cohorts in known functional protein domains (Fig. 5; Supplementary Table 11). Among those genes, SMARCAl has been associated with syndromic intellectual disability and Coffin-Siris-like

263 features by the Clinical Genome Resource (ClinGen) with moderate evidence. ${ }^{39}$

CDK16 and TRPC5 are novel genes associated with intellectual disability proaches but for which genetic evidence was limited (Fig. 6a-b). CDK16 encodes a protein 
medRxiv preprint doi: https://doi.org/10.1101/2022.02.16.22270779; this version posted February 17, 2022. The copyright holder for this preprint (which was not certified by peer review) is the author/funder, who has granted medRxiv a license to display the preprint in

two nucleotides leading to a frameshift (NM_006201.5: c.976_977del, p.(Trp326Valfs*5)) segregating in four males with ID, ASD, absence seizures and mild spasticity was reported in

271 this gene by Hu et al. ${ }^{18}$ Using exome sequencing, we identified a nonsense variant

(c.1039G > T, p.(Gly347Cys)) affecting a highly conserved amino acid of the kinase domain

(CADD PHRED score: 32) was identified by genome sequencing in a male patient with ID,

ASD and epilepsy, whose family history was compatible with X-linked inheritance (Fig. 6a recently reported in a patient with ASD by Satterstrom et al. ${ }^{41}$

TRPC5 encodes the short transient receptor potential channel 5, a channel permeable to calcium predominantly expressed in the brain. ${ }^{42} \mathrm{We}$ identified a missense variant in this gene (NM_012471.2:c.523C>T, p.(Arg175Cys), CADD PHRED score: 29.8) in three male siblings with ID and ASD. The variant was maternally inherited but absent from the maternal grandparents (Fig. 6b and d; Supplementary Table 12). We investigated the functional impact of the p.(Arg175Cys) variant on the TRPC5 channel using whole-cell patch-clamp. Immediately after break-in, HEK293 cells expressing mutant TRPC5 exhibited an increase in immediate current recorded compared with cell expressing wild-type TRPC5 ( $\mathrm{p}=0.009$ for outward current at $-80 \mathrm{mV}$ and $\mathrm{p}=0.002$ for inward current at $-80 \mathrm{mV}$; Fig.6 e-g), suggesting a constitutively active current. A nonsense variant (c.965G>A, p.(Trp322*)) was identified by exome sequencing in a patient with high-functioning ASD. An intragenic deletion of the first coding exon of TRPC5, encoding conserved ankyrin repeats, was previously reported in a patient with ASD who had a family history compatible with X-linked inheritance. ${ }^{43}$ In addition,

292 three de novo variants in TRPC5 (p.(Pro667Thr), p.(Arg71Gln), p.(Trp225*)) had been iden-

293 tified in patients with intellectual disability and/or autism disorders in the literature. ${ }^{21,44,45}$ 
medRxiv preprint doi: https://doi.org/10.1101/2022.02.16.22270779; this version posted February 17, 2022. The copyright holder for this preprint (which was not certified by peer review) is the author/funder, who has granted medRxiv a license to display the preprint in It is made available under a CC-BY-ND 4.0 International license .

Altogether, these results strongly suggest that pathogenic variants altering the functions of CDK16 and TRPC5 lead to novel X-linked disorders featuring ID and ASD.

\section{Discussion}

Male and female individuals tolerate pathogenic variants on chrX in different manners. Variants in X-linked genes have to be interpreted taking this complexity into account. We aimed at providing an inventory of disorder genes on chrX and predict genes that remain to be associated with human disease, assuming that they share similar characteristics. We first used a threshold approach to list genes similarly constrained during evolution, which are the most likely to lead to disease when altered by genetic variants. This revealed 127 novel genes sharing at least one constraint metric with known disorder genes and 35 sharing at least two. To avoid bias and limitations linked to this approach, we used a hypothesis-free neural network to differentiate genes associated with brain disorders from genes where damaging variants are tolerated (dispensable genes). The NN predicted 235 genes as putative disorder genes, including most of the genes uncovered by the threshold approach.

312 PHER and HGMD in predicted versus non-predicted genes, which strengthens the probability

313 that variants reported contribute to the patients' phenotypes and prompts the prioritization of

314 these genes in further genetic analyses. We notably highlight 13 genes in which several possi-

315 bly pathogenic variants in functional domains have been identified in patients, likely constituting novel neurodevelopmental disorder genes. Furthermore, a subset of predicted genes 
medRxiv preprint doi: https://doi.org/10.1101/2022.02.16.22270779; this version posted February 17, 2022. The copyright holder for this preprint (which was not certified by peer review) is the author/funder, who has granted medRxiv a license to display the preprint in

317 (e.g. OTUD5, FGF13, GLRA2 and GPKOW) have already been associated with human dis-

318 eases, although these associations had no OMIM Gene-Phenotype Relationship entries when

319 we started our study. Furthermore, we provide additional evidence that variants in two pre-

320 dicted genes, $C D K 16$ and TRPC5, likely cause novel X-linked disorders by gathering genetic

321 and clinical data of unrelated families with damaging variants in these genes.

Altogether, our gene-focused approach therefore suggests that less than half of genes associated with human pathology on chrX are known so far and many more remain to be characterized clinically, which challenges the recent estimation that X-chromosome has been saturated for disease genes. ${ }^{21}$ The differences in conclusions may come from recruitment bias in the DDD study, with inclusion of families with X-linked inheritance in more specific studies, as well as from the patient-driven approach itself, which only allows detecting what is statistically significant in a sample, no matter how large this sample is. It is indeed possible or even likely that phenotypes associated with genes we predict are ultra-rare, lethal in utero, difficult to recognize or assess clinically, or associated with atypical modes of X-linked inheritance, making their identification difficult using classical genetic approaches. this study, we observed a higher proportion of genes associated with disorders on chrX compared to autosomes. This finding suggests that family-driven approaches have been more efficient in identifying disorder-associated genes on this chromosome. Nevertheless, considering

338 disease-causing genes independently of their proportion, we also observed an enrichment of genes associated with specific neurological features such as ID, seizures, and language delay 
medRxiv preprint doi: https://doi.org/10.1101/2022.02.16.22270779; this version posted February 17, 2022. The copyright holder for this preprint (which was not certified by peer review) is the author/funder, who has granted medRxiv a license to display the preprint in

conveyed in the literature but, to our knowledge, this study is the first demonstrating the statistical significance of this finding using a systematic unbiased analysis. The reason why so many genes important for cognition and language are on a sex chromosome is fascinating but remains so far mysterious. ${ }^{46}$ ralogues (>95\% identity) compared to PMT/no-disorder genes, a finding that remained significant for predicted genes compared to non-predicted ones $\left(\mathrm{p}<2.2 \times 10^{-16} ; \mathrm{OR}=0.22\right)$. The consequence of the existence of paralogues for disorders is probably different depending on the expression of these paralogues and the ability of the gene product to compensate the function of the original genes. Interestingly, $20 \%$ of genes on chrX have paralogues with $>95 \%$ identity. This list includes copies or retrocopies on autosomes, a functional redundancy that has been attributed at least partly to the transcriptional silencing of chromosome $\mathrm{X}$ during spermatogenesis. ${ }^{47,48}$ Although many gene copies or retrocopies are specifically expressed in male germ cells, others are still broadly expressed and could therefore buffer genetic variants in the X-linked paralogous genes, as shown for $U P F 3 B$ and $U P F 3 A .{ }^{49}$ The existence of paralogues is also linked in some ways to the location in PAR regions and escape to XCI. Indeed, genes in PAR have paralogues on chrY and escape inactivation. ${ }^{50}$ Accordingly, 35 of the 231 predicted genes outside PAR also show some degree of escape from X inactivation

360 (Supplementary Table 1). Interestingly, genes escaping XCI outside PAR, including IQSEC2 and $K D M 5 C$, may lead to disorders manifesting in both sexes. ${ }^{10,12}$ Our study indicates that genes in PAR and genes with close paralogues are less likely to be associated with a disorder, suggesting that paralogues can compensate pathogenic variants in some $\mathrm{X}$-linked genes and raising the possibility of digenism or oligogenism in genes with redundant functions. 
medRxiv preprint doi: https://doi.org/10.1101/2022.02.16.22270779; this version posted February 17, 2022. The copyright holder for this preprint (which was not certified by peer review) is the author/funder, who has granted medRxiv a license to display the preprint in It is made available under a CC-BY-ND 4.0 International license.

Our study focused on coding genes and did not include genes encoding long non-coding RNA (lncRNA) or other RNA classes, which are however very abundant on chrX. Only a

368 few non-coding genes have been associated with disease so far and we believe that con-

369 straints and pathological mechanisms applying to non-coding genes are likely different from

370 those of coding genes. In this respect, our study only predicts genes associated with disorders

371 when affected by usual mutation types. Therefore, our findings do not exclude that non-pre-

372 dicted genes could lead to disease when associated with unusual mechanisms, such as gain of

373 a new function, dominant-negative impact on another gene, and ectopic expression of a gene

374 in the wrong tissue or at an abnormal time during development.

In conclusion, our study provides new insights into the complexity of X-linked disor-

377 ders and indicates that alternative approaches not initially based on patient cohorts are effec-

378 tive to reveal gene-disease associations. We provide a list of genes that are likely to be asso-

379 ciated with human disorders. Further studies are required to delineate these disorders clini-

380 cally and determine whether males and/or females harboring variants in these genes are af381 fected. 
medRxiv preprint doi: https://doi.org/10.1101/2022.02.16.22270779; this version posted February 17, 2022. The copyright holder for this preprint (which was not certified by peer review) is the author/funder, who has granted medRxiv a license to display the preprint in

It is made available under a CC-BY-ND 4.0 International license .

382

383

384

385

386

387

388

389

390

391

392

393

394

395

396

397

398

399

400

401

402

403

404

405

406

407

408

409

410

411

412

413

414

415

416

417

418

419

420

421

422

423

424

\section{References}

1. Balaton, B.P., Dixon-McDougall, T., Peeters, S.B. \& Brown, C.J. The eXceptional nature of the X chromosome. Hum Mol Genet 27, R242-R249 (2018).

2. Galupa, R. \& Heard, E. X-Chromosome Inactivation: A Crossroads Between Chromosome Architecture and Gene Regulation. Annu Rev Genet 52, 535-566 (2018).

3. Orstavik, K.H. X chromosome inactivation in clinical practice. Hum Genet 126, 36373 (2009).

4. Tukiainen, T. et al. Landscape of X chromosome inactivation across human tissues. Nature 550, 244-248 (2017).

5. Migeon, B.R. X-linked diseases: susceptible females. Genet Med 22, 1156-1174 (2020).

6. Kaur, S. \& Christodoulou, J. MECP2 Disorders. in GeneReviews $((R))$ (eds. Adam, M.P. et al.) (Seattle (WA), 1993).

7. Weaving, L.S. et al. Mutations of CDKL5 cause a severe neurodevelopmental disorder with infantile spasms and mental retardation. Am J Hum Genet 75, 1079-93 (2004).

8. Tao, J. et al. Mutations in the X-linked cyclin-dependent kinase-like 5 (CDKL5/STK9) gene are associated with severe neurodevelopmental retardation. Am J Hum Genet 75, 1149-54 (2004).

9. Snijders Blok, L. et al. Mutations in DDX3X Are a Common Cause of Unexplained Intellectual Disability with Gender-Specific Effects on Wnt Signaling. Am J Hum Genet 97, 343-52 (2015).

10. Mignot, C. et al. IQSEC2-related encephalopathy in males and females: a comparative study including 37 novel patients. Genet Med 21, 837-849 (2019).

11. Stamberger, H. et al. NEXMIF encephalopathy: an X-linked disorder with male and female phenotypic patterns. Genet Med 23, 363-373 (2021).

12. Carmignac, V. et al. Further delineation of the female phenotype with KDM5C disease causing variants: 19 new individuals and review of the literature. Clin Genet 98, 43-55 (2020).

13. Moortgat, S. et al. HUWE1 variants cause dominant X-linked intellectual disability: a clinical study of 21 patients. Eur J Hum Genet 26, 64-74 (2018).

14. Jolly, L.A. et al. Missense variant contribution to USP9X-female syndrome. NPJ Genom Med 5, 53 (2020).

15. Palmer, E.E. et al. De novo and inherited mutations in the X-linked gene CLCN4 are associated with syndromic intellectual disability and behavior and seizure disorders in males and females. Mol Psychiatry 23, 222-230 (2018).

16. Depienne, C. \& LeGuern, E. PCDH19-related infantile epileptic encephalopathy: an unusual X-linked inheritance disorder. Hum Mutat 33, 627-34 (2012).

17. Wieland, I. et al. Dissecting the molecular mechanisms in craniofrontonasal syndrome: differential mRNA expression of mutant EFNB1 and the cellular mosaic. Eur J Hum Genet 16, 184-91 (2008).

18. Hu, H. et al. X-exome sequencing of 405 unresolved families identifies seven novel intellectual disability genes. Mol Psychiatry 21, 133-48 (2016). 
medRxiv preprint doi: https://doi.org/10.1101/2022.02.16.22270779; this version posted February 17, 2022. The copyright holder for this preprint (which was not certified by peer review) is the author/funder, who has granted medRxiv a license to display the preprint in

It is made available under a CC-BY-ND 4.0 International license .

425

426

427

428

429

430

431

432

433

434

435

436

437

438

439

440

441

442

443

444

445

446

447

448

449

450

451

452

453

454

455

456

457

458

459

460

461

462

463

464

465

466

467

468

19. Tarpey, P.S. et al. A systematic, large-scale resequencing screen of X-chromosome coding exons in mental retardation. Nat Genet 41, 535-43 (2009).

20. Piton, A., Redin, C. \& Mandel, J.L. XLID-causing mutations and associated genes challenged in light of data from large-scale human exome sequencing. Am J Hum Genet 93, 368-83 (2013).

21. Martin, H.C. et al. The contribution of X-linked coding variation to severe developmental disorders. Nat Commun 12, 627 (2021).

22. Boukas, L., Bjornsson, H.T. \& Hansen, K.D. Promoter CpG Density Predicts Downstream Gene Loss-of-Function Intolerance. Am J Hum Genet 107, 487-498 (2020).

23. Karczewski, K.J. et al. The mutational constraint spectrum quantified from variation in 141,456 humans. Nature 581, 434-443 (2020).

24. Quartier, A. et al. Novel mutations in NLGN3 causing autism spectrum disorder and cognitive impairment. Hum Mutat 40, 2021-2032 (2019).

25. Chaudhry, A. et al. Phenotypic spectrum associated with PTCHD1 deletions and truncating mutations includes intellectual disability and autism spectrum disorder. Clin Genet 88, 224-33 (2015).

26. Halewa, J. et al. Novel missense mutations in PTCHD1 alter its plasma membrane subcellular localization and cause intellectual disability and autism spectrum disorder. Hum Mutat 42, 848-861 (2021).

27. Willemsen, M.H. et al. Involvement of the kinesin family members KIF4A and KIF5C in intellectual disability and synaptic function. J Med Genet 51, 487-94 (2014).

28. Kalantari, S. et al. Expanding the KIF4A-associated phenotype. Am J Med Genet A 185, 3728-3739 (2021).

29. Gowans, L.J.J. et al. Missense Pathogenic variants in KIF4A Affect Dental Morphogenesis Resulting in X-linked Taurodontism, Microdontia and DensInvaginatus. Front Genet 10, 800 (2019).

30. Beck, D.B. et al. Linkage-specific deubiquitylation by OTUD5 defines an embryonic pathway intolerant to genomic variation. Sci Adv 7(2021).

31. Tripolszki, K. et al. An X-linked syndrome with severe neurodevelopmental delay, hydrocephalus, and early lethality caused by a missense variation in the OTUD5 gene. Clin Genet 99, 303-308 (2021).

32. Fry, A.E. et al. Missense variants in the N-terminal domain of the A isoform of FHF2/FGF13 cause an X-linked developmental and epileptic encephalopathy. Am J Hum Genet 108, 176-185 (2021).

33. Steele, J.L. et al. Semaphorin-Plexin Signaling: From Axonal Guidance to a New XLinked Intellectual Disability Syndrome. Pediatr Neurol 126, 65-73 (2022).

34. Kotan, L.D. et al. Loss-of-function variants in SEMA3F and PLXNA3 encoding semaphorin-3F and its receptor plexin-A3 respectively cause idiopathic hypogonadotropic hypogonadism. Genet Med 23, 1008-1016 (2021).

35. Philips, A.K. et al. X-exome sequencing in Finnish families with intellectual disability--four novel mutations and two novel syndromic phenotypes. Orphanet $J$ Rare Dis 9, 49 (2014). 
medRxiv preprint doi: https://doi.org/10.1101/2022.02.16.22270779; this version posted February 17, 2022. The copyright holder for this preprint (which was not certified by peer review) is the author/funder, who has granted medRxiv a license to display the preprint in

It is made available under a CC-BY-ND 4.0 International license.

469

470

471

472

473

474

475

476

477

478

479

480

481

482

483

484

485

486

487

488

489

490

491

492

493

494

495

496

497

498

499

500

501

502

503

504

505

506

36. Pilorge, M. et al. Genetic and functional analyses demonstrate a role for abnormal glycinergic signaling in autism. Mol Psychiatry 21, 936-45 (2016).

37. Carroll, R. et al. Variant in the X-chromosome spliceosomal gene GPKOW causes male-lethal microcephaly with intrauterine growth restriction. Eur J Hum Genet 25, 1078-1082 (2017).

38. Kaplanis, J. et al. Evidence for 28 genetic disorders discovered by combining healthcare and research data. Nature 586, 757-762 (2020).

39. Strande, N.T. et al. Evaluating the Clinical Validity of Gene-Disease Associations: An Evidence-Based Framework Developed by the Clinical Genome Resource. Am J Hum Genet 100, 895-906 (2017).

40. Gillani, S.Q. et al. Regulation of PCTAIRE1 protein stability by AKT1, LKB1 and BRCA1. Cell Signal 85, 110032 (2021).

41. Satterstrom, F.K. et al. Large-Scale Exome Sequencing Study Implicates Both Developmental and Functional Changes in the Neurobiology of Autism. Cell 180, 568-584 e23 (2020).

42. Beck, A. et al. Conserved gating elements in TRPC4 and TRPC5 channels. J Biol Chem 288, 19471-83 (2013).

43. Mignon-Ravix, C. et al. Intragenic rearrangements in X-linked intellectual deficiency: results of a-CGH in a series of 54 patients and identification of TRPC5 and KLHL15 as potential XLID genes. Am J Med Genet A 164A, 1991-7 (2014).

44. Kosmicki, J.A. et al. Refining the role of de novo protein-truncating variants in neurodevelopmental disorders by using population reference samples. Nat Genet 49, 504-510 (2017).

45. de Ligt, J. et al. Diagnostic exome sequencing in persons with severe intellectual disability. N Engl J Med 367, 1921-9 (2012).

46. Graves, J.A., Gecz, J. \& Hameister, H. Evolution of the human X--a smart and sexy chromosome that controls speciation and development. Cytogenet Genome Res $\mathbf{9 9}$, 141-5 (2002).

47. Potrzebowski, L. et al. Chromosomal gene movements reflect the recent origin and biology of therian sex chromosomes. PLoS Biol 6, e80 (2008).

48. Marques, A.C., Dupanloup, I., Vinckenbosch, N., Reymond, A. \& Kaessmann, H. Emergence of young human genes after a burst of retroposition in primates. PLoS Biol 3, e357 (2005).

49. Nguyen, L.S. et al. Transcriptome profiling of UPF3B/NMD-deficient lymphoblastoid cells from patients with various forms of intellectual disability. Mol Psychiatry 17, 1103-15 (2012).

50. Raudsepp, T. \& Chowdhary, B.P. The Eutherian Pseudoautosomal Region. Cytogenet Genome Res 147, 81-94 (2015). 
medRxiv preprint doi: https://doi.org/10.1101/2022.02.16.22270779; this version posted February 17, 2022. The copyright holder for this preprint (which was not certified by peer review) is the author/funder, who has granted medRxiv a license to display the preprint in

It is made available under a CC-BY-ND 4.0 International license .

507 Supplementary Methods

\section{Protein-coding genes}

509 Annotations of genes in all chromosomes were downloaded from the HUGO Gene Nomen-

510 clature Committee (HGNC) database in November 2020 focusing on protein-coding genes

511 with approved status and present in the reference assembly. ${ }^{51} \mathrm{MED} 14 O S$ was excluded from

512 chrX-focused analysis due to its encoded protein being curated in Uniprot as "Product of a

513 dubious CDS prediction". Information concerning genes in PARs was also retrieved from

514 HGNC.

\section{Gene-phenotype relationships}

516 Gene associations with disorders and/or traits were retrieved from data files provided by

517 Online Mendelian Inheritance in Man (OMIM). Information concerning the Clinical Synopsis

518 of phenotypes was obtained through OMIM Search. OMIM morbid genes were annotated for

519 1) the availability of Clinical Synopsis data for any of the associated phenotypes, 2) the exist-

520 ence of Clinical Synopsis neurologic features in any of the associated phenotypes and 3) the

521 presence of terms related to intellectual disability, seizures, impaired language development,

522 impaired motor development, spasticity and ataxia among the Clinical Synopsis neurologic

523 features. For the latter and due to the free-text nature of the Clinical Synopsis data, synony-

524 mous terms and sentences of the above-mentioned clinical features were used and their com-

525 plete lists are shown in Supplementary Table 2. Genes were divided into three groups based

526 on the existence and type of their gene-phenotype relationships: 1) "confirmed" when associ-

527 ated with at least one confirmed monogenic disorder; 2) "PMT" for genes either with provi-

528 sional gene-phenotype relationship (P), or associated with susceptibility factors to multifacto- 
medRxiv preprint doi: https://doi.org/10.1101/2022.02.16.22270779; this version posted February 17, 2022. The copyright holder for this preprint (which was not certified by peer review) is the author/funder, who has granted medRxiv a license to display the preprint in

rial disorders (M) or with traits (T), which are labelled in the OMIM Gene Map with a ques-

530 tion mark, braces or brackets, respectively; 3) "no disorder" for genes showing no phenotype

531 associations. For each chromosome, we calculated the fraction of protein-coding genes that

532 are CS-genes and the fraction of CS-genes that contain non-specific or specific neurologic

533 features in the associated Clinical Synopsis data.

\section{Gene intolerance to variation}

535 Metrics related to intolerance of chrX genes to genetic variation (loss-of-function (LoF), mis-

536 sense and synonymous) were retrieved from the Genome Aggregation Database (gnomAD)

537 v2.1.1 ${ }^{23}$ after conversion of gene identifiers to HGNC approved symbols. For genes with

538 available data for multiple transcripts, the metrics of the one with lowest LoF observed/ex-

539 pected upper bound fraction (LOEUF) were kept.

\section{Gene expression data}

541 Median gene-level transcripts per million (TPM) for 54 tissues from the v8 release were

542 downloaded from the GTEx portal ${ }^{52}$. The robust tissue specificity measure tau ${ }^{53,54}$ was cal-

543 culated for chrX genes as previously described, aggregating the median expression of each

544 gene for the different brain regions into two values: i) the median of the values for the two

545 cerebellar regions and ii) the median of the values for the other brain tissues. ${ }^{22}$ Genes with tau

546 below 0.6 are broadly expressed, while tau higher than 0.6 indicates genes expressed in a re-

547 stricted number of tissues.

Additional expression data was downloaded from the BrainSpan Atlas of the Devel-

550 oping Human Brain. ${ }^{55}$ The Developmental Transcriptome Dataset contains gene summarized

551 RPKM (Reads Per Kilobase of transcript, per Million mapped reads) normalized expression 
medRxiv preprint doi: https://doi.org/10.1101/2022.02.16.22270779; this version posted February 17, 2022. The copyright holder for this preprint (which was not certified by peer review) is the author/funder, who has granted medRxiv a license to display the preprint in

It is made available under a CC-BY-ND 4.0 International license .

552 values generated across 13 developmental stages in 8-16 brain structures from a total of 42

553 individuals of both sexes. After conversion of RPKM to TPM and gene identifiers to HGNC

554 approved symbols, we restricted to genes on chrX and calculated the mean TPM according to

555 age groups, ignoring sex and tissue origin: 1) Pre-natal; 2) Post-natal; 2a) Post-natal 1: after

556 birth until four years-old (inclusive). 2b) Postnatal 2: older than four years old.

557

558

For the neural network, the expression data was stratified by sex: 1) we calculated the mean and variance expression of each gene for females and males independently, for brain,

560 cerebellar tissues and nerve, aggregating in one metavalue the data for the two cerebellar tis-

561 sues and in another the data for the other brain regions; 2) tau values were also calculated in-

562 dependently for females and males; 3) Brainspan mean and variance TPM for each age group was calculated separately for females and males.

\section{Canonical transcript selection}

565 The criteria for canonical transcript selection prioritized: i) MANE (Matched Annotation be-

566 tween NCBI and EBI) Select transcripts, which were independently identified by both En-

567 sembl and NCBI as the most biologically relevant; and ii) APPRIS-annotated transcripts ${ }^{56}$.

568 TSS, MANE, and APPRIS annotations of transcripts were retrieved from Ensembl Genes 102

569 via BioMart ${ }^{57}$. For most genes (ca. 80\%), the canonical transcripts belong to the MANE Se-

570 lect category. The longest transcript with APPRIS annotation was selected for ca. $20 \%$ of

571 genes. In one case, the only existing transcript was kept.

\section{Promoter CpG density}


medRxiv preprint doi: https://doi.org/10.1101/2022.02.16.22270779; this version posted February 17, 2022. The copyright holder for this preprint (which was not certified by peer review) is the author/funder, who has granted medRxiv a license to display the preprint in

It is made available under a CC-BY-ND 4.0 International license .

573 CpG density was calculated for the $4 \mathrm{~kb}$ region surrounding the transcription start site

574 (TSS $\pm 2 \mathrm{~kb})$ of the canonical transcripts of chrX protein-coding genes following previous pub-

575 lications. ${ }^{22,58}$ Promoter sequences were downloaded through UCSC Table Browser. ${ }^{59}$ The

576 CpG density, defined as the observed-to-expected CpG ratio, was calculated as follows: num-

577 ber of $\mathrm{CpG}$ dinucleotides / (number of $\mathrm{C} \times$ number of $\mathrm{G})$ ) $\times \mathrm{N}$, where $\mathrm{N}$ is the total number of 578 nucleotides in the sequence being analyzed.

579 Exon and promoter conservation across species

580 Nucleotide conservation across 100 vertebrate species was calculated using the phastCons

581 score obtained with the phastCons100way.UCSC.hg38 R package, ${ }^{60}$ and represents the prob-

582 ability that a given nucleotide is conserved (range 0 to 1 ). Exon-conservation score was cal-

583 culated for each gene on chrX as the average phastCons of all nucleotides belonging to the

584 gene coding sequence. Coding coordinates for the canonical transcripts were retrieved from

585 Ensembl Genes $102{ }^{57}$ using biomaRt R package. ${ }^{61,62}$ Promoter-conservation score for each

586 gene on chrX was calculated as the average phastCons score of all nucleotides $4 \mathrm{~kb}$ around the

587 TSS of the canonical transcript.

588 Distance to centromere and telomeres

589 The coordinates from centromeres and telomeres were downloaded through UCSC Table

590 Browser. We calculated the distance from the TSS of the canonical transcripts to the centro-

591 mere and to the telomere in the corresponding chromosomal arm.

\section{Annotation of encoded proteins}

593 Data referring to function, subcellular location, subunit structure, and gene ontology terms for

594 chrX encoded proteins were retrieved from Uniprot. ${ }^{63}$ 
medRxiv preprint doi: https://doi.org/10.1101/2022.02.16.22270779; this version posted February 17, 2022. The copyright holder for this preprint (which was not certified by peer review) is the author/funder, who has granted medRxiv a license to display the preprint in

It is made available under a CC-BY-ND 4.0 International license .

\section{Paralogues}

596 All paralogues from chrX genes were retrieve from Ensembl Genes $102^{57}$ using biomaRt R 597 package..$^{61,62}$ The $90^{\text {th }}, 95^{\text {th }}, 98^{\text {th }}$ and $99^{\text {th }}$ and $100^{\text {th }}$ percentiles were calculated for i) the per-

598 centage of paralogous sequence matching the query sequence and ii) the percentage of query 599 sequence matching the paralogue sequence. Only paralogues with both metrics above the $95^{\text {th }}$ 600 percentile were considered as close paralogues.

\section{X-chromosome inactivation}

602 The information on genes escaping X-chromosome inactivation (XCI) was obtained from

603 multiple publications. ${ }^{4,64-69}$ After converting gene identifiers from all studies into HGNC ap-

604 proved symbols, genes were divided into seven categories based on the agreement between

605 the various studies: 1) high confidence escapee and 2) high confidence non-escapee, when al-

606 most all studies agreed on one status; 3) low confidence escapee and 4) low confidence non-

607 escapee, whenever some studies disagreed but a higher number of studies reported one status;

608 5) variable escapee, when most studies stated variable escape; 6) discordant, when similar

609 number of studies agreed on both status; 7) not available, when there was not enough data to

610 have reliable evidence of XCI status.

\section{Features shared by disorder-causing genes}

612 To uncover no-disorder genes exhibiting similar characteristics to known disorder-causing

613 genes, we considered metrics showing enrichment of confirmed-disorder genes at one of the

614 extremes of the distribution with marked difference between confirmed-disorder and no-dis-

615 order genes. Then, we applied a threshold approach to categorize genes showing values

616 within the deciles enriched for confirmed disorder-causing genes for each of the considered 
medRxiv preprint doi: https://doi.org/10.1101/2022.02.16.22270779; this version posted February 17, 2022. The copyright holder for this preprint (which was not certified by peer review) is the author/funder, who has granted medRxiv a license to display the preprint in

It is made available under a CC-BY-ND 4.0 International license .

617 metrics. The minimum number of criteria showing enrichment for confirmed disorder-caus-

618 ing genes was used as the minimum number of criteria required to consider a PMT or no-dis-

619 order gene as having similar features to disorder-causing genes.

621 Genes were pre-classified based on 1) the type of associations with disorders and/or traits (confirmed, PMT, no-disorder), 2) the association with a brain disorder and 3) the tolerance to loss-of-function (LoF) variants (Extended Data Fig. 5). The list of confidently LoF-tolerant genes based on the gnomAD dataset was retrieved from data files from Karczewski et al. (2020) and consists of genes with at least one homozygous LoF variants. ${ }^{16}$ Genes showing no homozygous LoF variants were considered LoF-intolerant.

\section{Neural Network}

628 Information regarding the data fed into the neural network is in Supplementary Tables 7 and

629 8. We used a simple multilayer perceptron (MLP) network with 3 inner layers of size 128

630 nodes, 64 nodes and 32 nodes with rectified linear unit (ReLU) activation function and a sin-

631 gle output node with sigmoid activation. The weights were initialized with a random normal

632 distribution with a bias of zero, and batch normalization and a dropout of 0.5 were applied

633 between all layers. Training was performed with a batch size of 5 and data shuffling between

634 epochs using stochastic gradient descent (SGD) with a learning rate of 1e-3, no decay, and a

635 binary crossentropy / log loss as the objective function.

636 Class labels for the training data $T$ are "Cbi" (C1, value 1.0) and "NDt" (C0, value 0.0) (Ex-

637 tended Data Fig. 5; Supplementary Table 8). Beforehand columns of the training data were

638 separately normalized to $[0 ; 1]$ via min-max-scaling.

639 To validate the model we performed a 10 -fold cross validation by scikit-learn K-Fold ${ }^{70}$, 
medRxiv preprint doi: https://doi.org/10.1101/2022.02.16.22270779; this version posted February 17, 2022. The copyright holder for this preprint (which was not certified by peer review) is the author/funder, who has granted medRxiv a license to display the preprint in

640 which randomly splits $T$ into ten non overlapping parts $T_{0}$ to $T_{9}$ each containing $10 \%$ of the

641 data (Extended Data Fig. 4). Ten networks are trained. Each network $N_{i}$ is trained on the nine

642 parts $\left\{P_{j} \mid j \neq i\right\}$. Afterwards $N_{i}$ is applied to the remaining unseen part $P_{i}$ to create estimation $643 E_{i}$.

644 We then concatenate all partial estimations to get full estimation $\cup_{i} E_{i}=E$ for each gene in $645 T$. Together with the known classes $\mathrm{C} 0$ and $\mathrm{C} 1$ for each gene, we estimate a threshold t for 646 given false discovery rate d. First define functions $C 1(t)$ and $C 0(t)$ returning all genes of

647 class $\mathrm{C} 1$ respectively $\mathrm{C} 0$ with estimation score $<t$. For $t>0.5$ we can consider a gene with 648 label T0 to be false positive. Thereby for a given $t$ the empirical FDR can be measured by $649 T 1(t) /(T 0(t)+T 1(t))$. By calculating the FDR threshold by estimations on ten different 650 neural networks, each applied on unseen data, we ensure that the threshold is not biased by 651 overfitting. FDR thresholds were calculated as 0.8152034 (FDR 0.05) and 0.9745963

$652 \quad($ FDR $<0.01)$

653 Finally, a full network $N$ is trained on the full data $T$ and applied on the complete data set

654 with scaled column by the former min-max-scaling. The inferred score for each gene, repre655 sents the estimated probability for an association between the gene and a brain diseases.

656 All computational operations were performed in python with sklearn ${ }^{70}$ for normalization and

657 keras for building and training the neural network. ${ }^{71}$ Seeds for numpy, K-Fold and Tensor658 flow were set to 1094795585.

\section{Known mutations}

661 The number of indels, nonsense, splice site and missense variants reported in PMT and no-

662 disorder genes were retrieved from the Human Gene Mutation Database (HGMD) Profes-

663 sional 2020.3 (Qiagen) and DECIPHER, ${ }^{72}$ and normalized by the CDS length. DECIPHER 
medRxiv preprint doi: https://doi.org/10.1101/2022.02.16.22270779; this version posted February 17, 2022. The copyright holder for this preprint (which was not certified by peer review) is the author/funder, who has granted medRxiv a license to display the preprint in It is made available under a CC-BY-ND 4.0 International license .

664 variants include DDD variants and patient sequence variants that are not benign or likely be665 nign.

\section{Developmental disorders gene databases}

667 chrX genes were annotated for their classification in SysID

668 (https://www.sysid.dbmr.unibe.ch/) ${ }^{73}$ and Gene2Phenotype (https://www.ebi.ac.uk/gene2phenotype $)^{74}$ developmental disorders databases, which list genes associated with intellectual 670 disability or developmental disorders.

672 De novo variants in predicted genes were retrieved from Kaplanis et al. ${ }^{38}$ and Martin et al. ${ }^{21}$

673 In addition, we examined variants in predicted genes identified in unsolved cases with

674 developmental disorders from two different cohorts: a cohort from Hôpital Pitié-Salpêtrière

675 (APHP, Paris, France), which mainly includes patients with intellectual disability or

676 neurological disorders (6500 individuals from 2346 families) and a cohort of patients with

677 dysgenesis of the corpus callosum, associated with learning or intellectual disabilities from

678 University of California San Francisco (UCSF; 1399 individuals from 463 families).

679 Informed consent of the legal representatives and appropriate approval of an ethics

680 committee, according to the French and American laws, have been obtained. Variant data and

681 clinical information were shared anonymously. Only damaging variants (i.e. variants leading

682 to a premature termination codon or missense variants with CADD PHRED scores $\geq 25$ ) in

683 NN-predicted genes meeting at least one LME criterion were kept for further analysis. 
medRxiv preprint doi: https://doi.org/10.1101/2022.02.16.22270779; this version posted February 17, 2022. The copyright holder for this preprint (which was not certified by peer review) is the author/funder, who has granted medRxiv a license to display the preprint in

It is made available under a CC-BY-ND 4.0 International license .

685 HEK293 cells were transiently transfected with a plasmid expressing TRPC5-GFP WT or

686 p.Arg175Cys mutant channels. Currents were recorded from green fluorescent cells using the

687 whole-cell configuration of the patch-clamp technique 16 to $24 \mathrm{~h}$ after transfection at room

688 temperature. Voltage-clamp recordings were performed using an Axopatch 200B amplifier

689 and a Digidata 1440 Analogue/Digital interface (Axon Instruments). Data were low-pass fil-

690 tered at $2 \mathrm{kHz}$, digitized at $10 \mathrm{kHz}$ and analysed offline using Clampfit software. Currents

691 were recorded during a $500 \mathrm{~ms}$ voltage ramp from $-100 \mathrm{mV}$ to $100 \mathrm{mV}$ applied from a hold-

692 ing potential of $-100 \mathrm{mV}$ every $5 \mathrm{~s}$. Series resistance was not compensated, and no leak sub-

693 traction was performed. Data were not corrected offline for voltage error and liquid junction

694 potential. The pipette solution contained (in $\mathrm{mM}$ ): $\mathrm{NaCl} 8$, Cs-methanesulfonate $120, \mathrm{MgCl} 2$

695 1, $\mathrm{CaCl} 2$ 3.1, EGTA 10, HEPES 10, $\mathrm{pH}$ adjusted to 7.3 with $\mathrm{CsOH}$. The extracellular solu-

696 tion contained (in $\mathrm{mM}$ ): $\mathrm{NaCl} 140, \mathrm{MgCl} 2$ 1, $\mathrm{CaCl} 2$ 2, HEPES 10, glucose 10, $\mathrm{pH}$ adjusted to

6977.2 with $\mathrm{NaOH}$. Immediate currents were recorded upon break-in (using patch pipettes that

698 contained $100 \mathrm{nM}$ free $\mathrm{Ca} 2+)$. The mutant currents are readily distinguished even in the ab-

699 sence of agonist stimulation, indeed the current-voltage relationship (IV) was similar to that

700 described in the literature, showing inward and outward ('double') rectification, giving some-

701 thing that is roughly 'Nshaped'. Englerin A (100nM) was applied to the cell expressing WT

702 and mutant TRPC5 without immediate current upon break-in to confirm its functional expres-

703 sion.

\section{Statistics}

705 Fisher's tests were performed for each chromosome to determine associations between: i)

706 genes being present in the specific chromosome and genes having an associated phenotype

707 with Clinical Synopsis data (CS-genes); ii) CS-genes being in the specific chromosome and 
medRxiv preprint doi: https://doi.org/10.1101/2022.02.16.22270779; this version posted February 17, 2022. The copyright holder for this preprint (which was not certified by peer review) is the author/funder, who has granted medRxiv a license to display the preprint in

It is made available under a CC-BY-ND 4.0 International license .

708 CS-genes having non-specific or specific neurologic features described in the Clinical Synop-

709 sis data. For chrX, Fisher's tests were performed to compute the enrichment/depletion of con-

710 firmed disorder-associated genes in each decile of the distribution of continuous variables.

711 Odds ratios were $\log 2$ transformed and indicate enrichment or depletion of genes, for positive

712 or negative values, respectively $\left(10^{-4}\right.$ was added prior to transformation, whenever necessary

713 to deal with $\log$ of 0 issue). $P$-values were adjusted for multiple comparisons using Bonfer-

714 roni correction. For gene prediction, Fisher's tests were performed to calculate the association

715 between genes being confirmed-disorder genes and the number of predictors. Mann-Whitney

716 U test followed by Bonferroni correction for multiple testing was used to assess the coding-

717 sequence length difference between groups of genes.

718

719 Data availability

720 All data are available in the main text or supplementary materials. We used data from HGNC

721 (https://www.genenames.org/), OMIM (https://www.omim.org/), gnomAD v2.1.1

722 (https://gnomad.broadinstitute.org/), GTEx Portal (https://gtexportal.org/home/), BrainSpan

723 Atlas of the Developing Human Brain (https://www.brainspan.org/), Ensembl

724 (https://www.ensembl.org/index.html), UCSC Table Browser (https://genome.ucsc.edu/cgi-

725 bin/hgTables), Uniprot (https://www.uniprot.org/), Human Gene Mutation Database

726 (http://www.hgmd.cf.ac.uk/ac/index.php), DECIPHER (https://www.deciphergenomics.org/),

727 SysID database (https://www.sysid.dbmr.unibe.ch/), Gene2Phenotype

728 (https://www.ebi.ac.uk/gene2phenotype) and CADD - Combined Annotation Dependent De-

729 pletion (https://cadd.gs.washington.edu/).

730

731 Code availability 
medRxiv preprint doi: https://doi.org/10.1101/2022.02.16.22270779; this version posted February 17, 2022. The copyright holder for this preprint (which was not certified by peer review) is the author/funder, who has granted medRxiv a license to display the preprint in

It is made available under a CC-BY-ND 4.0 International license .

732 The following publicly available software packages were used to perform analyses: biomaRt (https://bioconductor.org/packages/release/bioc/html/biomaRt.html),

tion/html/phastCons100way.UCSC.hg38.html), rstatix (https://cran.r-project.org/web/pack-

ages/rstatix/index.html), numpy (https://numpy.org/), scikit-learn K-Fold

(https://github.com/scikit-learn/scikit-learn) and Tensorflow (https://www.tensorflow.org/).

\section{Supplementary references}

740

51. Braschi, B. et al. Genenames.org: the HGNC and VGNC resources in 2019. Nucleic Acids Res 47, D786-D792 (2019).

52. Consortium, G.T. The GTEx Consortium atlas of genetic regulatory effects across human tissues. Science 369, 1318-1330 (2020).

53. Yanai, I. et al. Genome-wide midrange transcription profiles reveal expression level relationships in human tissue specification. Bioinformatics 21, 650-9 (2005).

54. Kryuchkova-Mostacci, N. \& Robinson-Rechavi, M. A benchmark of gene expression tissue-specificity metrics. Brief Bioinform 18, 205-214 (2017).

55. Miller, J.A. et al. Transcriptional landscape of the prenatal human brain. Nature 508, 199-206 (2014).

56. Rodriguez, J.M. et al. APPRIS: annotation of principal and alternative splice isoforms. Nucleic Acids Res 41, D110-7 (2013).

57. Yates, A.D. et al. Ensembl 2020. Nucleic Acids Res 48, D682-D688 (2020).

58. Gardiner-Garden, M. \& Frommer, M. CpG islands in vertebrate genomes. J Mol Biol 196, 261-82 (1987).

59. Karolchik, D. et al. The UCSC Table Browser data retrieval tool. Nucleic Acids Res 32, D493-6 (2004).

60. Siepel, A. et al. Evolutionarily conserved elements in vertebrate, insect, worm, and yeast genomes. Genome Res 15, 1034-50 (2005).

61. Durinck, S. et al. BioMart and Bioconductor: a powerful link between biological databases and microarray data analysis. Bioinformatics 21, 3439-40 (2005).

62. Durinck, S., Spellman, P.T., Birney, E. \& Huber, W. Mapping identifiers for the integration of genomic datasets with the R/Bioconductor package biomaRt. Nat Protoc 4, 1184-91 (2009).

63. UniProt, C. UniProt: a worldwide hub of protein knowledge. Nucleic Acids Res 47, D506-D515 (2019).

64. Cotton, A.M. et al. Landscape of DNA methylation on the X chromosome reflects $\mathrm{CpG}$ density, functional chromatin state and X-chromosome inactivation. Hum Mol Genet 24, 1528-39 (2015).

65. Carrel, L. \& Willard, H.F. X-inactivation profile reveals extensive variability in Xlinked gene expression in females. Nature 434, 400-4 (2005). 
medRxiv preprint doi: https://doi.org/10.1101/2022.02.16.222707799; this version posted February 17, 2022. The copyright holder for this preprint (which was not certified by peer review) is the author/funder, who has granted medRxiv a license to display the preprint in

It is made available under a CC-BY-ND 4.0 International license.

66. Wainer Katsir, K. \& Linial, M. Human genes escaping X-inactivation revealed by single cell expression data. BMC Genomics 20, 201 (2019).

67. Balaton, B.P., Cotton, A.M. \& Brown, C.J. Derivation of consensus inactivation status for X-linked genes from genome-wide studies. Biol Sex Differ 6, 35 (2015).

68. Zhang, Y. et al. Genes that Escape X-Inactivation in Humans Have High Intraspecific Variability in Expression, Are Associated with Mental Impairment but Are Not Slow Evolving. Mol Biol Evol 33, 302 (2016).

69. Oliva, M. et al. The impact of sex on gene expression across human tissues. Science 369(2020).

70. Pedregosa, F. et al. Scikit-learn: Machine learning in Python. Journal of Machine Learning Research, 2825-2830 (2011).

71. Chollet, F. Keras: the Python deep learning API. (2005).

72. Firth, H.V. et al. DECIPHER: Database of Chromosomal Imbalance and Phenotype in Humans Using Ensembl Resources. Am J Hum Genet 84, 524-33 (2009).

73. Kochinke, K. et al. Systematic Phenomics Analysis Deconvolutes Genes Mutated in Intellectual Disability into Biologically Coherent Modules. Am J Hum Genet 98, 14964 (2016).

74. Thormann, A. et al. Flexible and scalable diagnostic filtering of genomic variants using G2P with Ensembl VEP. Nat Commun 10, 2373 (2019). 
medRxiv preprint doi: https://doi.org/10.1101/2022.02.16.22270779; this version posted February 17, 2022. The copyright holder for this preprint (which was not certified by peer review) is the author/funder, who has granted medRxiv a license to display the preprint in

It is made available under a CC-BY-ND 4.0 International license .

790

791

792

793

794

795

796

797

798

799

800

801

802

803

804

805

806

807

808

809

810

811

812

\section{Competing Interests statement}

814 The authors declare no competing interests.

\section{Acknowledgements} DECIPHER project was provided by Wellcome.

\section{Author Contributions}

The authors thank the patients with $C D K 16$ and TRPC5 pathogenic variants and their family for their participation in this study. We kindly thank Mrs Céline Cuny for Sanger sequencing analysis of the patient with TRPC5 missense variant. Electrophysiological experiments were carried out at the electrophysiology core facility of ICM funded from the program "Investissements d'avenir" ANR-10-IAIHU-06. We thank Universitätsklinikum Essen, University Duisburg-Essen, the Deutsche Forschungsgemeinschaft (DFG), the Tom-Wahlig-Stiftung (TWS), the Deutsche Stiftung Neurologie (DSN), and Assistance Publique des Hôpitaux de Paris (APHP) for their financial support to the research studies conducted by the authors. E.L. and F.K. are associated with the FOR 2488 project (DFG, Project number 287074911). This study makes use of data generated by the DECIPHER community. A full list of centres who contributed to the generation of the data is available from https://deciphergenomics.org/about/stats and via email from contact@deciphergenomics.org. Funding for the

E.L. and C.De. conceived and supervised the study. E.L. and C.S. performed the computations. E.L., I.P., C.Da., A.R., T.K., S.K., N.D., and C.E. carried out the experiments. A.K., B.G., E.S., C.N., J.P., B.D-B., L.V., A.P.A.S., E.K.V., J.A.J.V., F.J.K., F.T.M-T., M.S., P.S., S.G.M.F., E.A., E.H.S., F.E., J.B., B.K., C.M., D.H., J-L.M., J.G., V.M.K., B.H., and A.P. contributed analysis, data and/or critically revised the manuscript for intellectual content. E.L. and C.De. drafted the manuscript. All authors reviewed and approved the manuscript. 
confirmed monogenic disorder PMT

no disorder b 20001 $\quad$ O Intellectual disability

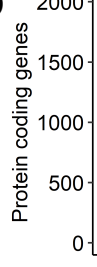

confirmed $+\mathrm{C}$

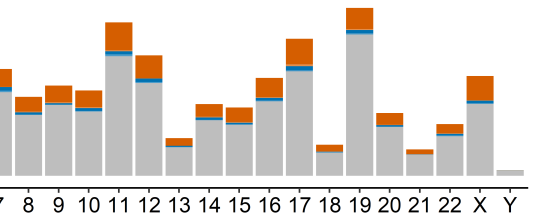

confirmed-cs

PMT +CS PMT -CS no disorder

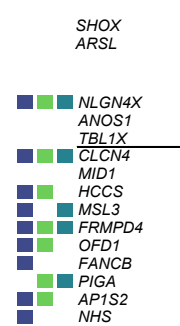

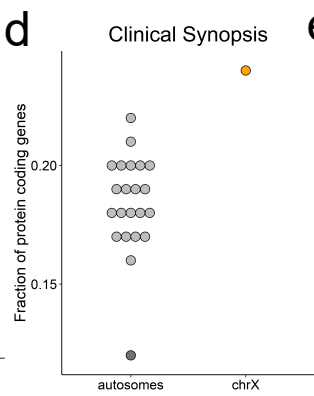

- depletion $\odot$ enrichment $\odot$ not significant

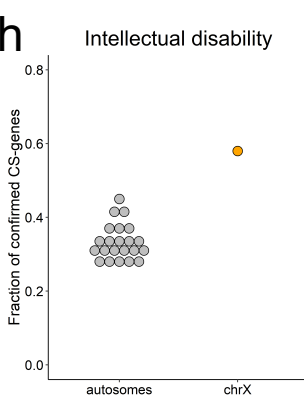

- enrichment 0 not significant

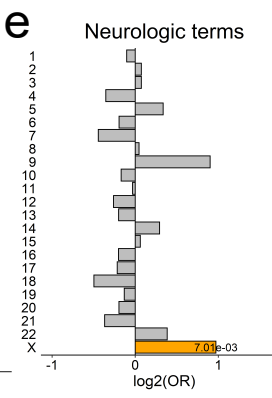

$\square$ enrichment $\square$ not significant f Neurologic terms

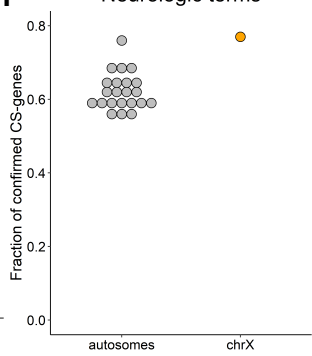

$\circ$ enrichment $\circ$ not significant

Seizures

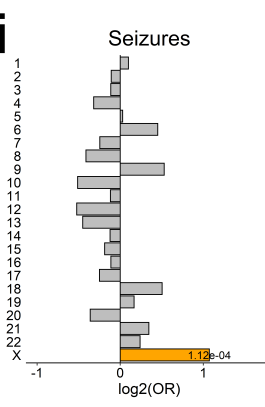

$\square$ enrichment $\square$ not significant

$\mathrm{m}$

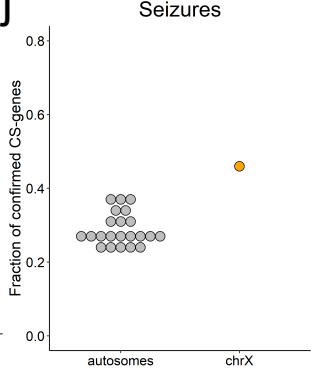

SYN1
FTSJ1

- $\quad$ PORCN

WAS

PQBP1
SLC35A

SLC35A2
WDR45

SYP

CCDC22
USP27X

SHROOM4

- KDM5C

- SMC1A

- $\mathrm{HSD} 17 \mathrm{~B} 10$

$\square$ - $P H F 8$

FGD1
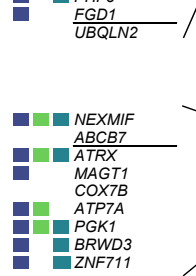

$\square$ enrichment $\square$ not significant

I

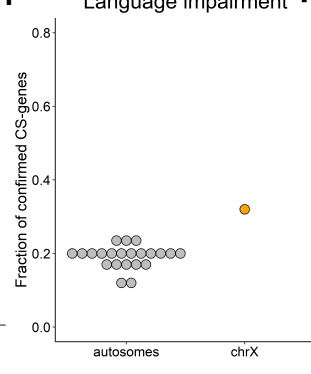

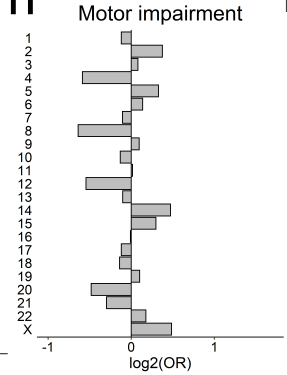

$\square$ not significant

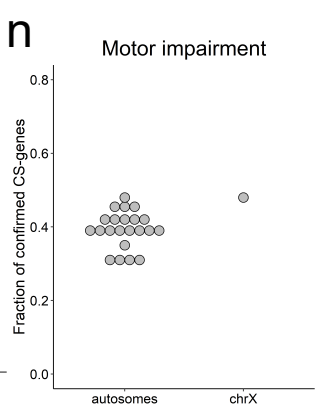

1
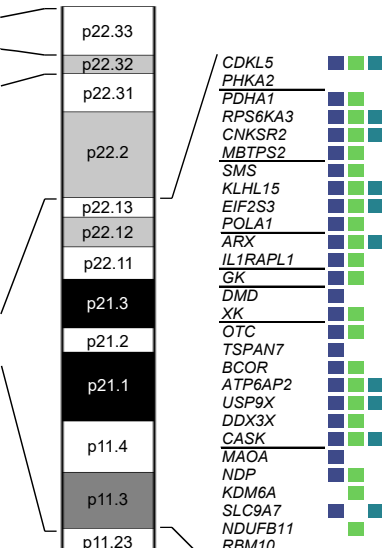

p21.1

p11.4

p11.3

p11.23

p11.22

p11.21

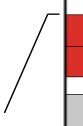

/

$A R H G E F 9$
$A M E T 1$ $A M E R 1$
$Z C 4 H 2$ ZCAH2 LAS1L
OR
OPHN1 OPHN1 IGBP1 $D L G 3$ IL2RG
MED12 GJB1 NONO
TAF1 TAF1
OGT

HDAC8

SLC16
RLIM

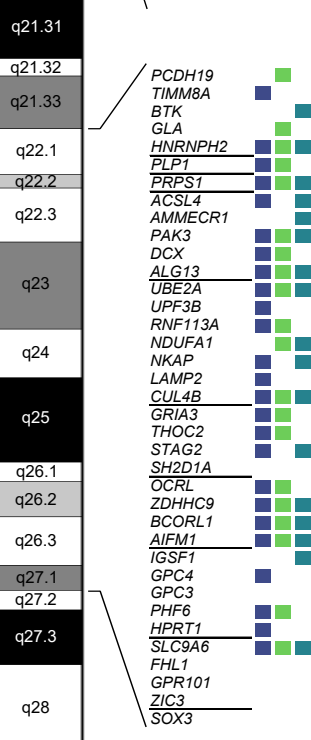


medRxiv preprint doi: https://doi.org/10.1101/2022.02.16.22270779; this version posted February 17, 2022. The copyright holder for this preprint (which was not certified by peer review) is the author/funder, who has granted medRxiv a license to display the preprint in It is made available under a CC-BY-ND 4.0 International license .

815 Fig. 1: Disorder genes across chromosomes. a, Number of protein-coding genes on chrX.

816 Genes associated with at least one monogenic disorder: orange, confirmed genes; blue: genes

817 with provisional associations (P), associated with susceptibility factors to multifactorial disor-

818 ders (M) or traits (T) (altogether: PMTs); grey: genes without known phenotypes (no-disorder

819 genes). b, Number of protein-coding genes per chromosome. Dark and light colors represent

820 genes with Clinical Synopsis (CS) data for at least one of the associated phenotypes (+CS) or

821 without CS (-CS), respectively. c, Per chromosome enrichment/depletion of protein-coding

822 genes with at least one associated phenotype comprising Clinical Synopsis data (confirmed

823 CS-genes). d, Fraction of confirmed CS-genes among protein-coding genes. e-n. Predomi-

824 nance of chrX genes associated with neurologic features. e, $\mathbf{g}, \mathbf{i}, \mathbf{k}$ and $\mathbf{m}, \mathrm{Per}$ chromosome

825 enrichment/depletion of genes with non-specific neurologic features (e), intellectual disability

826 (g), seizures (i), language impairment (k) or motor development (m). f, h, $\mathbf{j}, \mathbf{l}$ and $\mathbf{n}$, Fraction

827 of genes associated with non-specific neurologic features (f), intellectual disability (h), sei-

828 zures (j), language impairment (l) or motor development (n). c-n, Yellow, enrichment; dark-

829 grey, depletion; light grey, not significant. Terms corresponding to the same neurological

830 clinical features were used in OMIM searches (Supplementary Table 2). Only significant p-

831 values are shown (Fisher's test followed by Bonferroni correction for multiple testing; Sup-

832 plementary Tables 4 and 5). o, Scheme of genes associated with neurological features on

833 chrX. Squares next to the genes represent association with intellectual disability (blue), sei-

834 zures (green) or language impairment (cyan). A horizontal line separates genes present in dif-

835 ferent chromosome bands. 
medRxiv preprint doi: https://doi.org/10.1101/2022.02.16.22270779; this version posted February 17, 2022. The copyright holder for this preprint (which was not certified by peer review) is the author/funder, who has granted medRxiv a license to display the preprint in It is made available under a CC-BY-ND 4.0 International license.

836 Fig. 2: Prediction of disorder-genes. a-c, Density plots showing the distribution of LOEUF

837 (a), misZ (b) and exon-conservation score (c) according to gene group. Confirmed disorder 838 genes (orange), PMT genes (blue), no-disorder genes (grey). Vertical dashed lines separate

839 deciles of the overall distribution. Grey areas depict deciles for which confirmed disorder-as-

840 sociated genes are enriched (related to Extended Data Fig. 2). d, Overview of the approaches

841 used to uncover features shared by disorder genes and to predict new putative disorder-genes

842 (details in Supplementary Methods). e, Euler diagrams showing the number of genes ful-

843 filling LOEUF (L), misZ (M) and exon-conservation (E) criteria for confirmed (left), PMT

844 (middle) and no-disorder genes (right). Thresholds: LOEUF $\leq 0.326$, misZ $\geq 2.16$, exon-con-

845 servation score $\geq 0.9491$. Genes fulfilling at least two LME criteria are shown in green (light

846 or dark green for two or three criteria, respectively). Genes meeting only one of the metrics

847 are shown in different shades of grey (dark to light: LOEUF, misZ, exon-conservation). f, Eu-

848 ler diagrams showing the number of genes fulfilling LME criteria (LME, green), predicted by

849 the neural network (yellow) or both (blue) for confirmed (left), PMT (middle) and no-disor-

850 der genes (right). e and $\mathbf{f}$, Genes neither predicted by the neural network nor meeting LME

851 criteria are shown in white. 
$\mathrm{LME}=3$

CXorf56** NN L M E

* ID candidate genes

** Current primary ID genes / ID data freeze

$\mathrm{NN}+\mathrm{LME} \geq 1$

LME=3

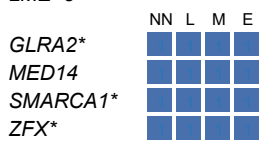

LME $=2$

CDK16*

CSTF2*

DCAF12L1

EIF1AX

ERCC6L

FAM120C*

FAM199X

GRIPAP1

GSPT2*

IL1RAPL2

KLHL13

MAGED1

NKRF

OTUD5**

RBBP7

RPS4X

RPS6KA6

SCML1

SCML2

SLC25A14

SLC38A5

SUV39H1

TENM1

TMEM164

TRPC5

USP11

WDR44

WNK3

ZC3H12B

ZMYM3*

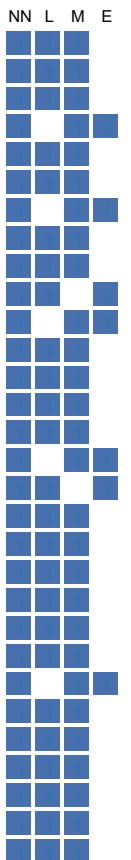

* ID candidate genes

** Current primary ID genes

LME only

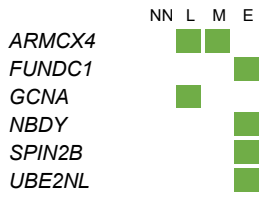

LME $=2$

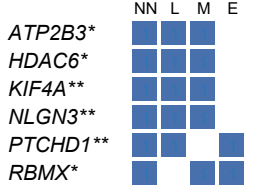

$\mathrm{LME}=1$

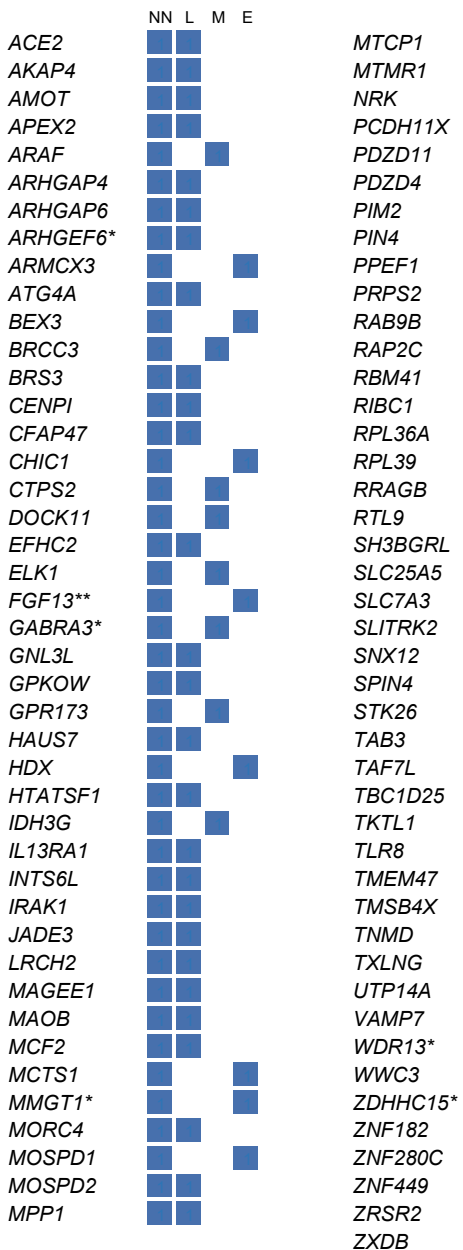

LME $=1$

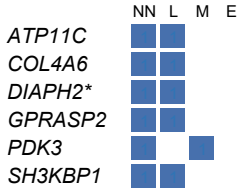

d $N N+L M E=0$
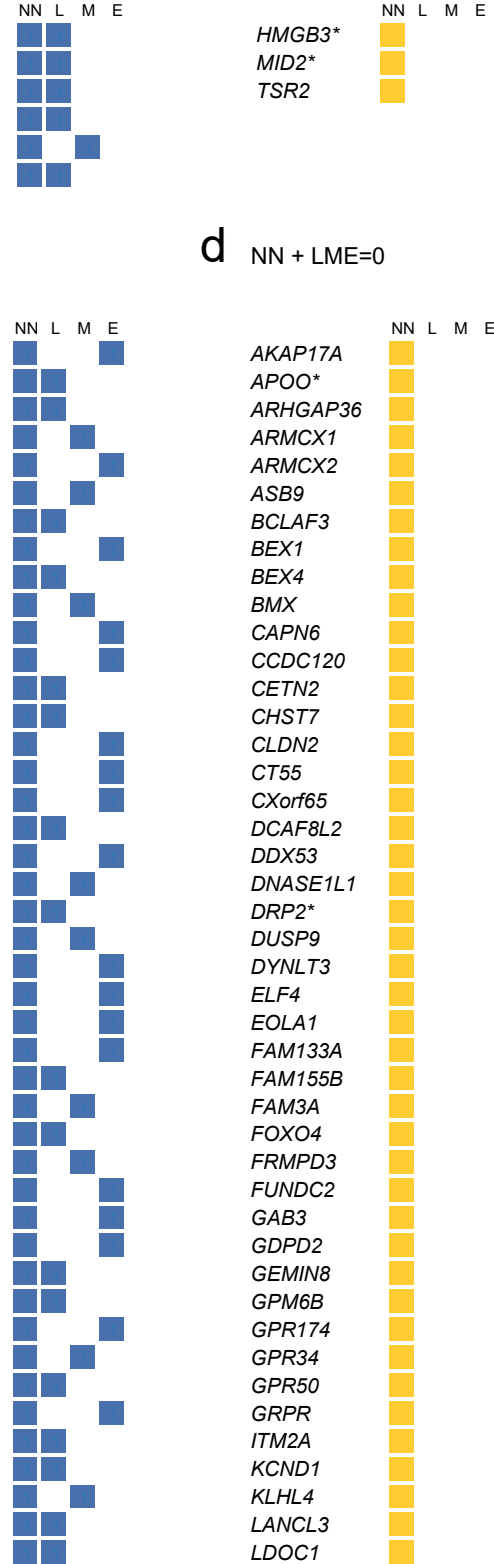
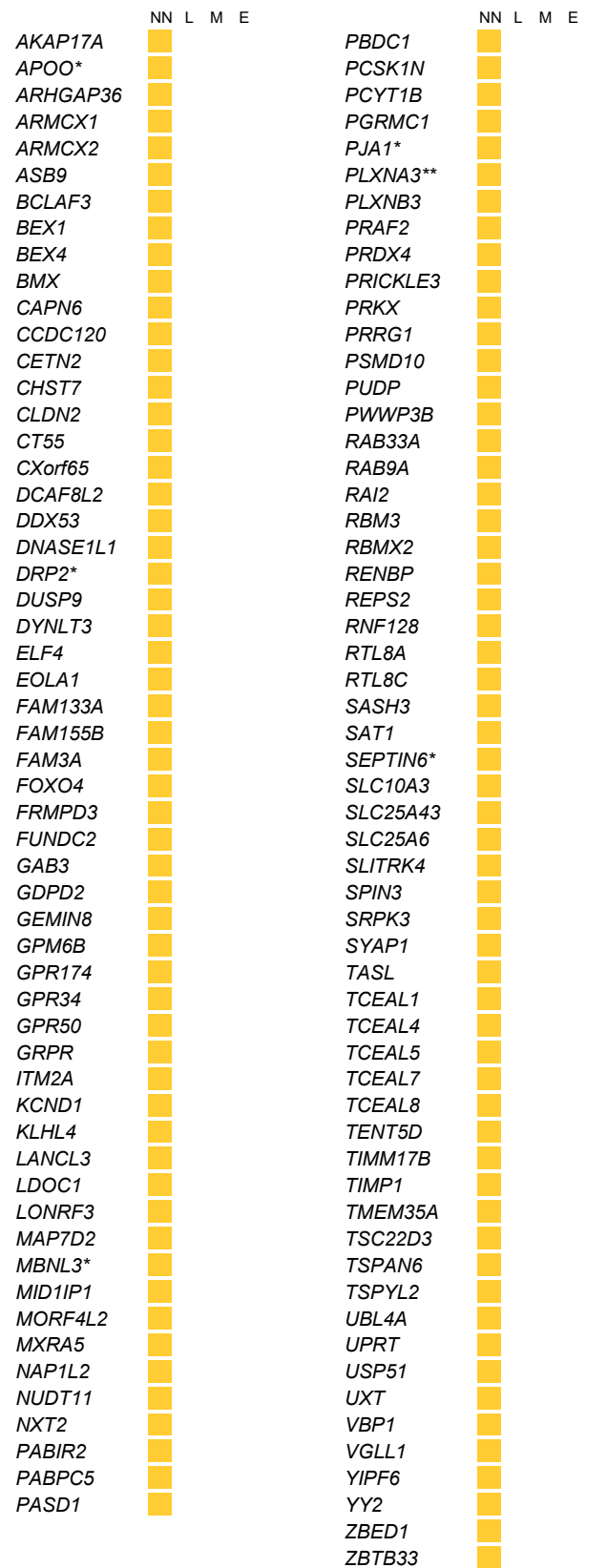
medRxiv preprint doi: https://doi.org/10.1101/2022.02.16.22270779; this version posted February 17, 2022. The copyright holder for this preprint (which was not certified by peer review) is the author/funder, who has granted medRxiv a license to display the preprint in It is made available under a CC-BY-ND 4.0 International license

852 Fig. 3: Different evidence strength for the predicted disorder-associated genes. a-d, PMT

853 (a, b) and no-disorder genes $(\mathbf{c}, \mathbf{d})$ predicted by the neural network as possibly disease-associ-

854 ated, either fulfilling (a, c) or not LME criteria $(\mathbf{b}, \mathbf{d})$. Genes present in the SysID database as

855 "ID candidate genes" (*) and "Current primary ID" or "ID data freeze" (**) are marked. e,

856 No-disorder genes meeting LME criteria but not predicted by the neural network. 
medRxiv preprint doi: https://doi.org/10.1101/2022.02.16.22270779; this version posted February 17, 2022. The copyright holder for this preprint (which was not certified by peer review) is the author/funder, who has granted medRxiv a license to display the preprint in It is made available under a CC-BY-ND 4.0 International license.

857 Fig. 4: External supporting evidence for the predicted disorder-associated genes. a and

858 b, Known point mutations in no-disorder genes. Boxplot showing the number of known mu-

859 tations reported in HGMD and DECIPHER (a) or their value normalized by coding-sequence

860 (CDS) length (b) according to their predicted status. No-disorder genes meeting LME criteria

861 but not predicted by the neural network were omitted from the analysis. Box plot elements

862 are defined as follows: center line: median; box limits: upper and lower quartiles; whiskers:

$8631.5 \times$ interquartile range; points: outliers. Related to Supplementary Table 9. c, Number of no-

864 disorder genes present in the SysID database according to their predicted status. 
Variants: LoF missense splicing

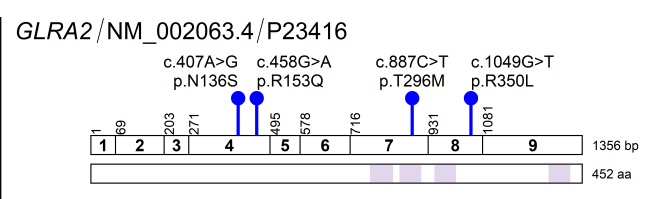

SMARCA1/NM_001282874.2/P28370
Domain

Transmembrane
Repeat (NHL, YD or WD40)

Zinc finger
ZFX/NM_003410.4/P17010

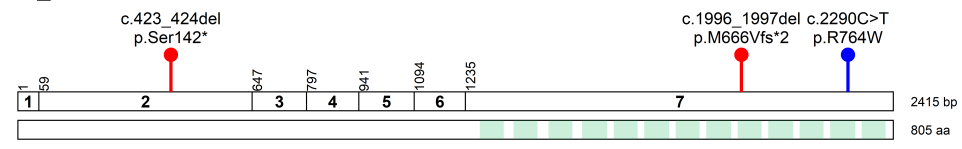

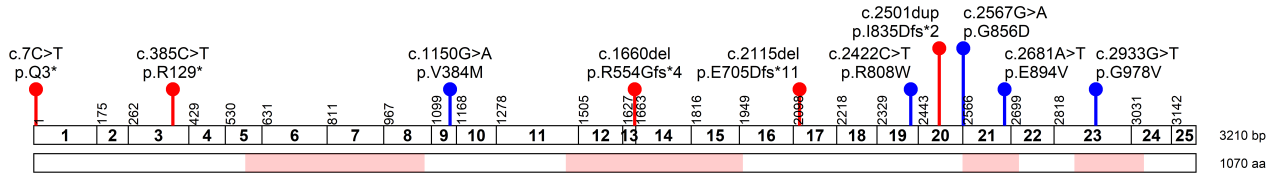

| GSPT2/NM_018094.5/Q8IYD1

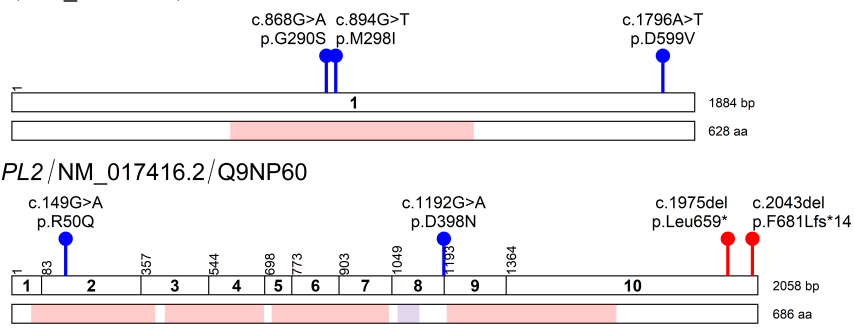

TENM1 /NM_014253.3/Q9UKZ4

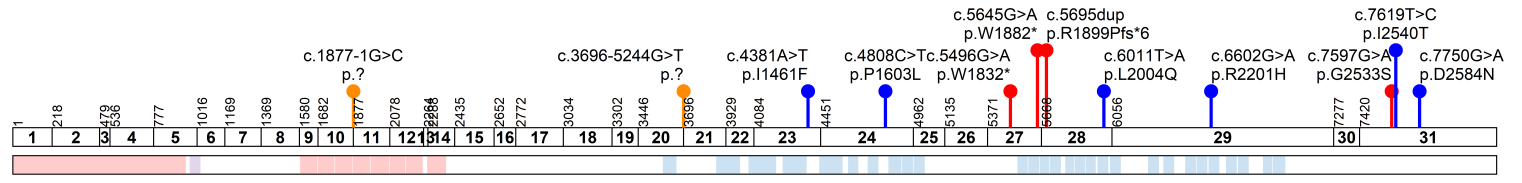

$8175 \mathrm{bp}$

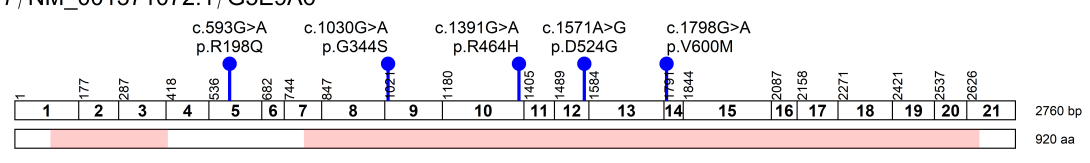

ZC3H12B/NM_001010888.4/Q5HYM0
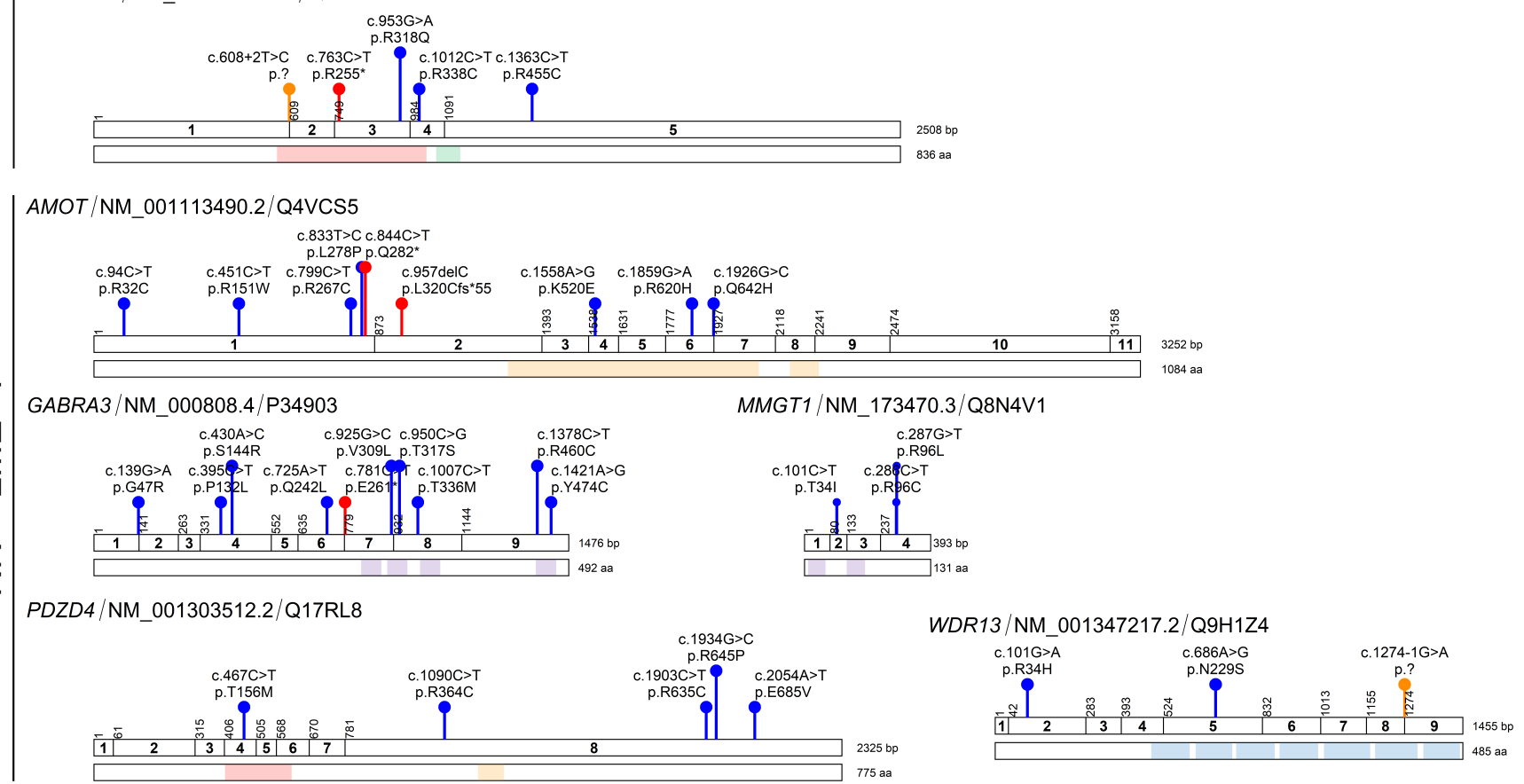
medRxiv preprint doi: https://doi.org/10.1101/2022.02.16.22270779; this version posted February 17,2022 . The copyright holder for this preprint (which was not certified by peer review) is the author/funder, who has granted medRxiv a license to display the preprint in It is made available under a CC-BY-ND 4.0 International license .

865 Fig. 5: Damaging variants in selected predicted disorder-associated genes. Schematic

866 representation of the coding exons, protein domains (when present) and available damaging

867 variants (truncating or $\mathrm{CADD} \geq 25$ ) for each selected predicted gene. Types of variants are

868 shown in different colors: lof-of-function (LoF, red), missense (blue), splicing (orange). Pro-

869 tein functional domains are shown: domains (light red), transmembrane segments (purple),

870 NHL, YD or WD40 repeats (light blue), coiled-coils (yellow), zinc-fingers (green). HGVS

871 cDNA and HGVS protein descriptions are shown. The corresponding RefSeq identifier of the

872 MANE Select transcript and Uniprot identifier are shown for each gene. Details of variants

873 displayed in this figure appear in Supplementary Table 11. 


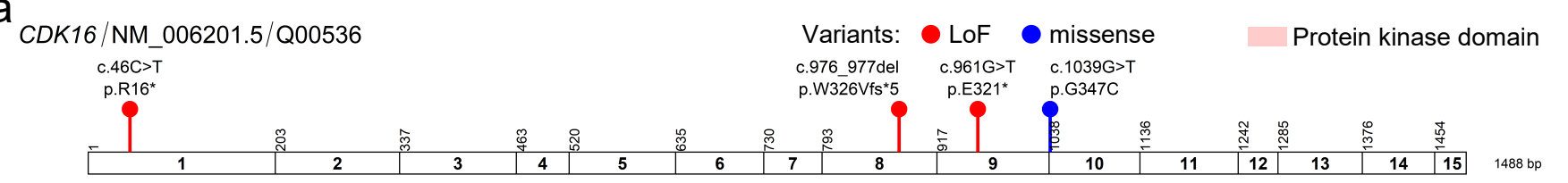

\section{CDK16}

NM_006201.5: c.1039G >T NM_006201.5: c.961G >T p.(Gly347Cys)
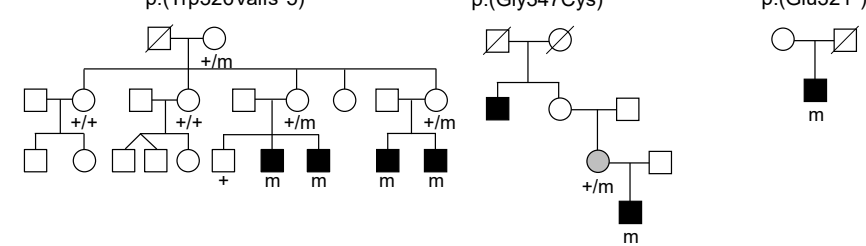
NM_006201.5: c.976_977del p.(Trp326Valfs ${ }^{\star} 5$ ) e

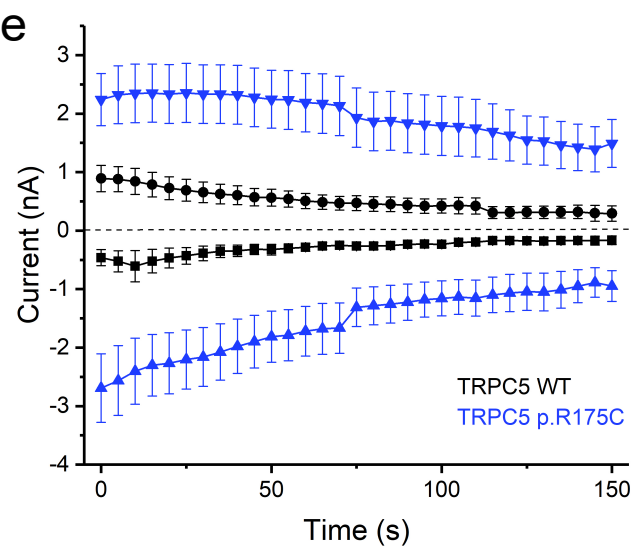

f

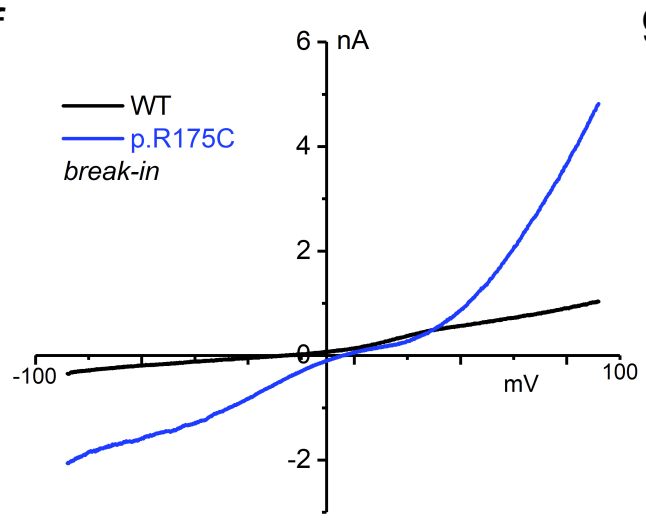

d NM_012471.2:C.523C

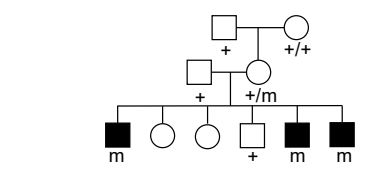

\section{TRPC5} 10 $2919 \mathrm{bp}$ 973 aа NM_012471.2: c.965
p.(Trp322*)

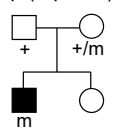
496 aa 
medRxiv preprint doi: https://doi.org/10.1101/2022.02.16.22270779; this version posted February 17, 2022. The copyright holder for this preprint (which was not certified by peer review) is the author/funder, who has granted medRxiv a license to display the preprint in

It is made available under a CC-BY-ND 4.0 International license .

874 Fig. 6: Validation of selected predicted disorder-associated genes: CDK16 and TRPC5. a

875 and $\mathbf{b}$, Schematic representation of the coding exons, protein domains and variants of CDK16

876 (a) and TRPC5 (b). Variant types: loss-of-function (LoF, red), missense (blue). c, Pedigrees

877 of the three families with CDK16 variants. The pedigree of family with c.976_977del,

878 p.(Trp326Valfs*5) was adapted from Hu et al. $(2016)^{18}$. The two remaining families are un-

879 published. d, Pedigrees of the three families with TRPC5 variants. The family with an intra-

880 genic exon deletion was reported in Mignon-Ravix et al. $(2014)^{43}$. The two other families are

881 novel. e-g, Functional characterization of TRPC5 p.R175C by whole-cell patch-clamp record-

882 ings showing that the mutation renders the mutant channel constitutively opened. e, Time

883 course of inward and outward current amplitudes measured at $+80 \mathrm{mV}$ and $-80 \mathrm{mV}$ in

884 HEK293 cells transiently expressing WT (black) and mutant TRPC5 (red) in presence of

$885100 \mathrm{nM}$ free $\mathrm{Ca}^{2+}$ in the pipette. Values are reported as mean $\pm \mathrm{SEM}$. Recordings started few

886 seconds after the rupture. f, Representative whole-cell current-voltage (I-V) relationships of

887 WT and mutant TRPC5 channels current obtained shortly after break-in $(\leq 10 \mathrm{~s})$ with $100 \mathrm{nM}$

888 free $\mathrm{Ca}^{2+}$ in the pipette. $\mathrm{g}$, Boxplot of $\mathrm{WT}$ and mutant whole-cell current at $-80 \mathrm{mV}$ and +80

$889 \mathrm{mV}$ after break-in (one-way ANOVA with Dunnett's post hoc test). The number of independ-

890 ent recordings appears in brackets. Details of variants displayed in this figure appear in Sup-

891 plementary Table 12. 